\title{
On the roles of sulphuric acid and low-volatility organic vapours in the initial steps of atmospheric new particle formation
}

\author{
P. Paasonen ${ }^{1}$, T. Nieminen ${ }^{1}$, E. Asmi ${ }^{2}$, H. E. Manninen ${ }^{1}$, T. Petäjä ${ }^{1}$, C. Plass-Dülmer ${ }^{3}$, H. Flentje ${ }^{3}$, W. Birmili ${ }^{4}$, \\ A. Wiedensohler ${ }^{4}$, U. Hõrrak ${ }^{5}$, A. Metzger ${ }^{6}$, A. Hamed ${ }^{7}$, A. Laaksonen ${ }^{2,7}$, M. C. Facchini ${ }^{8}$, V.-M. Kerminen ${ }^{1,2}$, and \\ M. Kulmala ${ }^{1,9}$ \\ ${ }^{1}$ University of Helsinki, Helsinki, Finland \\ ${ }^{2}$ Finnish Meteorology Institute, Helsinki, Finland \\ ${ }^{3}$ Meteorological Observatory Hohenpeissenberg, German Meteorological Service, Germany \\ ${ }^{4}$ Institute for Tropospheric Research, Leipzig, Germany \\ ${ }^{5}$ University of Tartu, Tartu, Estonia \\ ${ }^{6}$ Ionicon Analytik GmbH, Innsbruck, Austria \\ ${ }^{7}$ University of Eastern Finland, Kuopio, Finland \\ ${ }^{8}$ Institute of Atmospheric Sciences and Climate, Bologna, Italy \\ ${ }^{9}$ Stockholm University, Stockholm, Sweden
}

Received: 16 April 2010 - Published in Atmos. Chem. Phys. Discuss.: 5 May 2010

Revised: 28 September 2010 - Accepted: 6 October 2010 - Published: 30 November 2010

\begin{abstract}
Sulphuric acid and organic vapours have been identified as the key components in the ubiquitous secondary new particle formation in the atmosphere. In order to assess their relative contribution and spatial variability, we analysed altogether 36 new particle formation events observed at four European measurement sites during EUCAARI campaigns in 2007-2009. We tested models of several different nucleation mechanisms coupling the formation rate of neutral particles $(J)$ with the concentration of sulphuric acid $\left(\left[\mathrm{H}_{2} \mathrm{SO}_{4}\right]\right)$ or low-volatility organic vapours ([org]) condensing on sub-4 nm particles, or with a combination of both concentrations. Furthermore, we determined the related nucleation coefficients connecting the neutral nucleation rate $J$ with the vapour concentrations in each mechanism. The main goal of the study was to identify the mechanism of new particle formation and subsequent growth that minimizes the difference between the modelled and measured nucleation rates. At three out of four measurement sites - Hyytiälä (Finland), Melpitz (Germany) and San Pietro Capofiume (Italy) - the nucleation rate was closely connected to squared sulphuric acid concentration, whereas in Hohenpeissenberg (Germany) the low-volatility organic vapours were observed
\end{abstract}

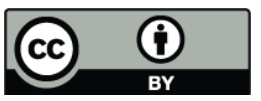

Correspondence to: P. Paasonen (pauli.paasonen@helsinki.fi) to be dominant. However, the nucleation rate at the sulphuric acid dominant sites could not be described with sulphuric acid concentration and a single value of the nucleation coefficient, as $K$ in $J=K\left[\mathrm{H}_{2} \mathrm{SO}_{4}\right]^{2}$, but the median coefficients for different sites varied over an order of magnitude. This inter-site variation was substantially smaller when the heteromolecular homogenous nucleation between $\mathrm{H}_{2} \mathrm{SO}_{4}$ and organic vapours was assumed to take place in addition to homogenous nucleation of $\mathrm{H}_{2} \mathrm{SO}_{4}$ alone, i.e., $J=K_{\mathrm{SA}_{1}}\left[\mathrm{H}_{2} \mathrm{SO}_{4}\right]^{2}+K_{\mathrm{SA} 2}\left[\mathrm{H}_{2} \mathrm{SO}_{4}\right][\mathrm{org}]$. By adding in this equation a term describing homomolecular organic vapour nucleation, $K_{\mathrm{s} 3}[\mathrm{org}]^{2}$, equally good results were achieved. In general, our results suggest that organic vapours do play a role, not only in the condensational growth of the particles, but also in the nucleation process, with a site-specific degree.

\section{Introduction}

A large number of observations have shown that atmospheric new particle formation by nucleation takes place frequently in the continental boundary layer, as well as in the free troposphere (e.g. Kulmala et al., 2004a; Kulmala and Kerminen, 2008; Venzac et al., 2008; Mirme et al., 2010). Under favourable conditions, nucleated particles grow into sizes in which they are able to produce new cloud condensation

Published by Copernicus Publications on behalf of the European Geosciences Union. 
nuclei (Lihavainen et al., 2003; Kerminen et al., 2005; Laaksonen et al., 2005; Whitehead et al., 2009; Wiedensohler et al., 2009). The important role of nucleation in the global aerosol budget and, thereby, in cloud microphysics and climate, has recently been demonstrated by many large-scale modelling studies (Spracklen et al., 2008; Makkonen et al., 2009; Merikanto et al., 2009; Pierce and Adams, 2009; Wang and Penner, 2009; Yu and Luo, 2009).

A successful simulation of aerosol dynamics in global climate or Earth System models requires mechanistic understanding on how the nucleation rate $(J)$ is connected with the concentrations of vapours participating in the nucleation process. At present such an understanding is far from complete. Both field measurements and laboratory experiments have identified sulphuric acid $\left(\mathrm{H}_{2} \mathrm{SO}_{4}\right)$ as the key player in atmospheric nucleation (e.g. Weber et al., 1997; Sipilä et al., 2010). The best relation between the nucleation rate and $\mathrm{H}_{2} \mathrm{SO}_{4}$ concentration is usually obtained when assuming $J \sim\left[\mathrm{H}_{2} \mathrm{SO}_{4}\right]^{n}$, where the exponent $n$ lies in the range 1-2 (Weber et al., 1997; Kulmala et al., 2006; Riipinen et al., 2007; Kuang et al., 2008; Paasonen et al., 2009; Sipilä et al., 2010). Such a relation is in stark contrast with existing thermodynamic nucleation theories, but it could be explained by activation-type (Kulmala et al., 2006) or kinetic (McMurry and Friedlander, 1979) nucleation involving $\mathrm{H}_{2} \mathrm{SO}_{4}$.

In addition to sulphuric acid, the atmospheric nucleation rate has been suggested as being affected by many other trace gases (see Kulmala and Kerminen, 2008). Among them, lowvolatile organic compounds are of specific interest for several reasons. First of all, large amounts of organic aerosol precursor vapours are emitted into the global atmosphere, and in the future such emissions might even be increased as a result of climate change (Kulmala et al., 2004b; Arneth et al., 2008; Pacifico et al., 2009; Rinne et al., 2009). Secondly, the contribution of secondary sources to the atmospheric organic aerosol load, in general, and to aerosol dynamics, in particular, seems to be much larger than previously thought (Hallquist et al., 2009; Jimenez et al., 2009). Thirdly, the growth of freshly-nucleated atmospheric aerosol particles cannot usually be explained without a significant contribution by vapours other than sulphuric acid (Weber et al., 1997; Birmili et al., 2003; Boy et al., 2005; Smith et al., 2008), and indirect chemical measurements indicate that organics are present in nm-sized and larger particles during atmospheric new particle formation events (O'Dowd et al., 2002; Laaksonen et al., 2008). Direct evidence on the participation of organics in the nucleation process has also been obtained in laboratory experiments (Zhang et al., 2004, 2009; Metzger et al., 2010).

The biggest gap of knowledge when linking atmospheric nucleation with organic vapours is the ignorance of the contributing species (e.g. Clayes et al., 2009). As a result, we neither know which organic vapours participate in nucleation, nor their physical and chemical properties or concentrations. In this paper, we aim to shed new light on the role of organic compounds in atmospheric nucleation. We will approach the problem by first assuming that both nucleation and initial growth of nucleated particles are determined by sulphuric acid and the same low-volatile organic vapour(s). By determining the particle growth rate and gaseous sulphuric acid concentration from measurements, we may calculate the "growth-equivalent" organic vapour concentration and investigate its relation to measured nucleation rates. Besides the simple first and second order mechanism based on sulphuric acid studied before (Kulmala et al., 2006), we will investigate six additional analogous nucleation mechanisms that involve this organic vapour concentration. Our analysis is based on measurements conducted within the EUCAARI project (Kulmala et al., 2009) at four different field sites in Central and Northern Europe.

\section{Materials and methods}

\subsection{Measurement sites}

The combined dataset used in this study was collected from four different stations around Europe (Fig. 1). The sites represent locations with a variable anthropogenic influence and gas phase pollutant levels. The stations also differ significantly in geographical latitude and, consequently, in terms of their surrounding ecosystems - varying from the rural Boreal forest (Hyytiälä) to Mediterranean agricultural areas (San Pietro Capofiume). The altitude range varies from close to sea level in the Po Valley to mountainous Hohenpeissenberg at $985 \mathrm{~m}$.

\subsubsection{Hyytiälä}

Hyytiälä (SMR) is a rural site in central southern Finland $\left(61^{\circ} 51^{\prime} \mathrm{N}, 24^{\circ} 17^{\prime} \mathrm{E}, 181 \mathrm{~m}\right.$ a.s.l.). The measurements in Hyytiälä were performed at SMEAR II (Station for Measuring Ecosystem-Atmosphere Relations, Hari and Kulmala, 2005) operated by the University of Helsinki. The station is located in a boreal coniferous forest consisting mainly of Scots pine (Pinus sylvestris L.). The biggest city nearby Hyytiälä, Tampere, is about $60 \mathrm{~km}$ from the site and has a population of about 200000 .

\subsubsection{Hohenpeissenberg (HPB)}

The Meteorological Observatory Hohenpeissenberg (e.g. Birmili et al., 2003), operated by the German Weather Service (DWD), is situated in rural southern Germany $\left(47^{\circ} 48^{\prime} \mathrm{N}, 11^{\circ} 0^{\prime} \mathrm{E}\right), 40 \mathrm{~km}$ north from the Alps. The observatory stands on top of the Hohenpeissenberg Mountain, at an altitude of $985 \mathrm{~m}$ a.s.l. and about $300 \mathrm{~m}$ above the surrounding countryside. The surroundings of the mountain are mainly meadows and forests. 


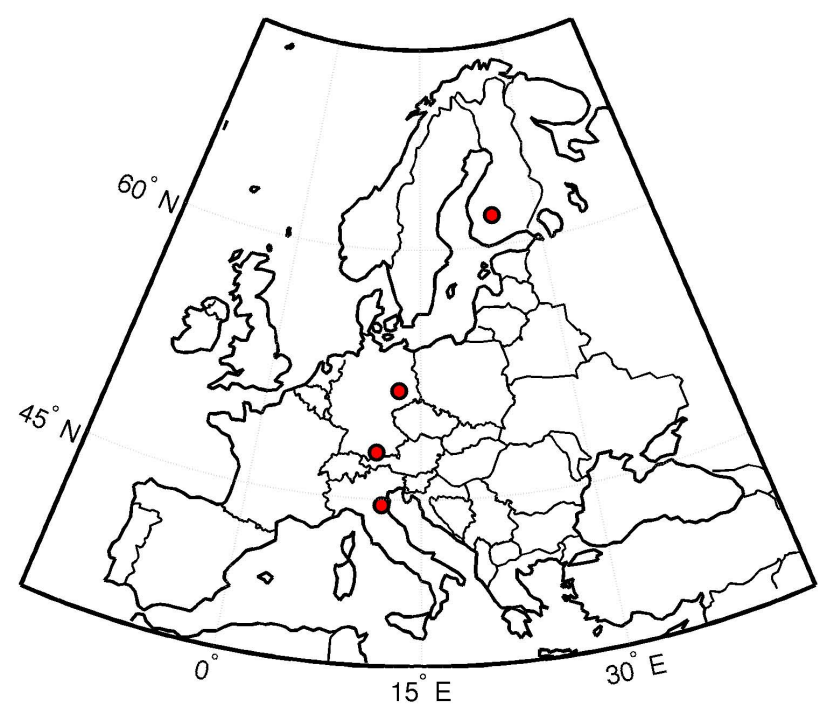

Fig. 1. Map of the measurement sites. Sites from north to south: Hyytiälä (Finland), Melpitz (Germany), Hohenpeissenberg (Germany) and San Pietro Capofiume (Italy).

\subsubsection{Melpitz}

Melpitz (MPZ; Engler et al., 2007) is a rural site in eastern Germany $\left(51^{\circ} 32^{\prime} \mathrm{N}, 12^{\circ} 54^{\prime} \mathrm{E}, 87 \mathrm{~m}\right.$ a.s.l.). The measurement site is operated by the Leibniz-Institute for Tropospheric Research (IfT), and is situated on a flat meadow surrounded by agricultural land. Even though Melpitz is clearly considered a rural observation site, the levels of anthropogenic pollution tend to be higher than in Hyytiälä or Hohenpeissenberg e.g. in terms of sulphur dioxide (Hamed et al., 2010), which is the prime anthropogenic precursor of $\mathrm{H}_{2} \mathrm{SO}_{4}$.

\subsubsection{San Pietro Capofiume (SPC)}

San Pietro Capofiume (e.g. Hamed et al., 2007) is located in Northern Italy, in a flat rural area in the eastern part of the Po Valley $\left(44^{\circ} 39^{\prime} \mathrm{N}, 11^{\circ} 37^{\prime} \mathrm{E}, 11 \mathrm{~m}\right.$ a.s.l.). The distance to the closest cities, Bologna and Ferrara, is about $40 \mathrm{~km}$. Po Valley is the largest industrial, trading and agricultural area in Italy with a high population density. During the measurements reported here, however, fairly clean conditions were encountered with the frequent influence of air masses from the Adriatic Sea.

\subsection{Instrumentation and measurements}

Similar sets of atmospheric particle measurements were carried out during the EUCAARI-campaigns at all four sites: in Hyytiälä from 1 April to 21 May 2007 (Manninen et al., 2009), in Hohenpeissenberg from 20 July 2007 to 28 December 2008, in Melpitz from 10 May to 31 May 2008 (Manninen et al., 2010), and in San Pietro Capofiume from 30 June to 12 July 2009. All four datasets included air ion and neutral particle size distributions, sulphuric acid concentrations and global radiation data. Both particle and sulphuric acid concentration measurements were performed at ground level.

\subsubsection{Ultrafine particle size distributions}

The air ion and neutral particle size distributions from 0.8 to $42 \mathrm{~nm}$ (mobility diameter) were recorded with Neutral cluster and Air Ion Spectrometers (NAIS; Kulmala et al., 2007; Asmi et al., 2009). The NAIS classifies the particles according to their electrical mobilities, which are further converted to mobility diameters. Ion concentrations are calculated from electrometer currents, both polarities being measured simultaneously with different electrometers. Additionally, the NAIS measures neutral particles based on the aerosol unipolar charging probability in the corona chargers, placed in front of the mobility analysers. The formed corona ions are further removed from the sample flow using electrical filters. One measurement cycle, consisting of ion, total (neutral + charged) and background signal measurements, is completed in five minutes. Prior to field measurements, all NAIS instruments were inter-compared and calibrated (Asmi et al., 2009).

\subsubsection{Sulphuric acid concentration}

The sulphuric acid concentrations were measured with Chemical Ionization Mass Spectrometers (CIMS; Berresheim et al., 2000; Petäjä et al., 2009). The CIMS is typically used with time resolutions between some seconds and a minute. In this study, we averaged the measured concentrations over 10 minutes. The measurements in Hohenpeissenberg, Melpitz and San Pietro Capofiume were performed with the CIMS of DWD, whereas in Hyytiälä the CIMS of the University of Helsinki (UHEL) was used. The two instruments are very similar, as the UHEL CIMS is built at the National Center for Atmospheric Research (NCAR, USA), and also the DWD CIMS is NCAR-type CIMS, though slightly modified (Berresheim et al., 2000). They also rely on the same calibration procedure.

Measuring sulphuric acid concentration is not a standard procedure hitherto. The sulphuric acid concentration measured with the UHEL CIMS has been compared to calculated concentration proxies in Hyytiälä (Petäjä et al., 2009). The measured concentrations agreed well with those calculated with the proxies. However, intercalibration of the CIMSs that were used has not been performed. Thus, we can not fully exclude the possibility of systematic differences in the sulphuric acid concentrations $\left[\mathrm{H}_{2} \mathrm{SO}_{4}\right]$ measured by different instruments (UHEL and DWD), regardless of their similarity. The uncertainty of the DWD instrument for $\mathrm{H}_{2} \mathrm{SO}_{4}$ has been estimated at 39\% (2-sigma) (Berresheim et al., 2000), and has been improved since. Thus, combined uncertainties might result in up to $50 \%$ systematic difference between both instruments in the worst case. Systematic differences in 
sulfuric acid measurements due to instrumental drift between the sites HPB, Melpitz and SPC, which were all measured by the same DWD CIMS instrument with identical calibration procedures, should not exceed $20 \%$.

\subsubsection{Ancillary data}

For the calculations, we also utilized the particle size distributions from $3 \mathrm{~nm}$ up to $800 \mathrm{~nm}$ in Melpitz, up to $1 \mu \mathrm{m}$ in Hyytiälä and up to $600 \mathrm{~nm}$ in SPC, all measured with a Differential Mobility Particle Sizer (DMPS; Hoppel, 1978; Aalto et al., 2001; Birmili et al., 1999), and distributions from $13 \mathrm{~nm}$ up to $900 \mathrm{~nm}$ in HPB measured with a Scanning Mobility Particle Sizer (SMPS).

Additionally, the basic meteorological data (global radiation, temperature, relative humidity, air pressure, and wind speed and direction) were available.

\subsection{Data analysis}

The goal of this study was to investigate the connections between the formation rate of neutral $2 \mathrm{~nm}$ size particles $\left(J_{2}\right)$, and the concentrations of sulphuric acid $\left(\left[\mathrm{H}_{2} \mathrm{SO}_{4}\right]\right)$ and other vapours condensing on particles from 2 to $4 \mathrm{~nm}$ in diameter $\left(d_{\mathrm{p}}\right)$. These vapours were assumed to be oxidized organic vapours and are, thus, marked with [org] hereafter.

In order to derive $J_{2}$ and [org] from the measurements, the particle growth rate (GR) is needed. The growth rate can be determined only if a new growing mode of particles with $d_{\mathrm{p}} \sim 2 \mathrm{~nm}$ is observed and can be distinguished from the size distribution, i.e. on nucleation event days (an example is given in Fig. 2a). Only those nucleation event days, for which a sufficiently unambiguous value for GR could be determined, were used in the analysis. Furthermore, the concentration of particles with diameters from 2 to $4 \mathrm{~nm}\left(N_{2-4}\right)$ is needed to calculate the $J_{2}$. The neutral particle concentration below $3 \mathrm{~nm}$ measured with the NAIS can be trusted only when reasonably high concentrations are obtained (Asmi et al., 2009). Thus, to attain reliable GR and $N_{2-4}$ values we included in the analysis only the data points measured during the nucleation events. The start and the end time of the events were determined visually from the total particle size distributions recorded with the NAIS (see Fig. 2a).

\subsubsection{The particle growth rate $\mathbf{G R}_{2-4}$}

The growth rate of particles from 2 to $4 \mathrm{~nm}$ in diameter $\left(d_{\mathrm{p}}\right)$ was determined from the ion size distribution recorded by the NAIS. The ion concentrations were used instead of the total concentrations, because the growing mode is typically better defined in the ion concentrations. The determination of the growth rate was made with the method presented by Hirsikko et al. (2005) as follows. The time series of ion concentrations at size classes having geometric mean diameter between 2 and $4 \mathrm{~nm}$ were examined separately. A normal distribution function was fitted in each time series of concentrations during the nucleation event. A linear fitting to the times corresponding to the maxima of these functions was made, resulting in the growth rate $\mathrm{GR}_{\text {det }}$ in units $\mathrm{nm} \mathrm{h}^{-1}$ (an example is given in Fig. 2b).

Manninen et al. (2009) assumed that the real growth rate from 2 to $3 \mathrm{~nm}$ might be a factor of 2 lower or higher than the average growth rate of particle population determined with the method described above. However, in the current study this factor was somewhat smaller, because we used only those nucleation events for which the determined growth rate seemed unambiguous.

From the sulphuric acid concentration $\left(\left[\mathrm{H}_{2} \mathrm{SO}_{4}\right]\right)$ measured with the CIMS we calculated the particle growth rate related to sulphuric acid condensation $\left(\mathrm{GR}_{\mathrm{H}_{2} \mathrm{SO}_{4}}\right)$. The sulphuric acid concentration required for growth rate of $1 \mathrm{~nm} / \mathrm{h}$ in particle size range $d_{\mathrm{p}}=2-4 \mathrm{~nm}$ was obtained from Nieminen et al. (2010) (see also Lehtinen and Kulmala, 2003)

$$
\begin{aligned}
& C_{\mathrm{GR}=1, \mathrm{H}_{2} \mathrm{SO}_{4}}=\frac{2 \rho_{\mathrm{p}} d_{\mathrm{v}}}{\gamma m_{\mathrm{v}} \Delta t} \cdot \sqrt{\frac{\pi m_{\mathrm{v}}}{8 k T}} \\
& \cdot\left[\frac{2 x_{1}+1}{x_{1}\left(x_{1}+1\right)}-\frac{2 x_{0}+1}{x_{0}\left(x_{0}+1\right)}+2 \ln \left(\frac{x_{1}\left(x_{0}+1\right)}{x_{0}\left(x_{1}+1\right)}\right)\right],
\end{aligned}
$$

where $x_{0}$ and $x_{1}$ are the ratios of the vapour molecule diameter $\left(d_{\mathrm{v}}\right)$ to the initial and final particle diameter, respectively. The mass of a sulphuric acid vapour molecule $m_{\mathrm{v}}$ was calculated with the parameterization by Kurtén et al. (2007), describing the sulphuric acid hydrate distribution as a function of ambient temperature $(T)$ and relative humidity. For the density of the particle $\left(\rho_{\mathrm{p}}\right)$ we used a value of $1440 \mathrm{~kg} \mathrm{~m}^{-3}$. This is an average of the density of sulphuric acid-watermixture ( $\rho=1670 \mathrm{~kg} \mathrm{~m}^{-3}$, the average at the conditions of the data points used in the analysis, calculated with the parameterizations by Kurtén et al., 2007, and Jaecker-Voirol, 1988) and the assumed density of the other vapour(s) participating in the nucleation and/or the initial growth of the particles $\left(\rho=1200 \mathrm{~kg} \mathrm{~m}^{-3}\right.$, see Sect. 2.3.2). Finally, the vapour molecule diameter $d_{\mathrm{v}}$ was calculated separately for each data point as a function of temperature and humidity, by using the mass $m_{\mathrm{v}}$ and the density of the sulphuric acid-water-mixture.

Actually, the calculated $C_{\mathrm{GR}=1, \mathrm{H}_{2} \mathrm{SO}_{4}}$ describes the theoretical minimum $\mathrm{H}_{2} \mathrm{SO}_{4}$ concentration leading to a growth rate of $1 \mathrm{~nm} \mathrm{~h}^{-1}$, as it is assumed that every sulphuric acid molecule colliding with the particle is attached to it. However, in laboratory experiments by Sipilä et al. (2010) the observed growth was in good agreement with the growth calculated with Eq. (1). This gives us confidence in the assumption of collision limited growth rate. For further details concerning the derivation of Eq. (1), we refer the reader to Nieminen et al. (2010).

The growth rate related to $\mathrm{H}_{2} \mathrm{SO}_{4}$ condensation during the timeframe used for the determination of $\mathrm{GR}_{\text {det }}$ was calculated directly as 

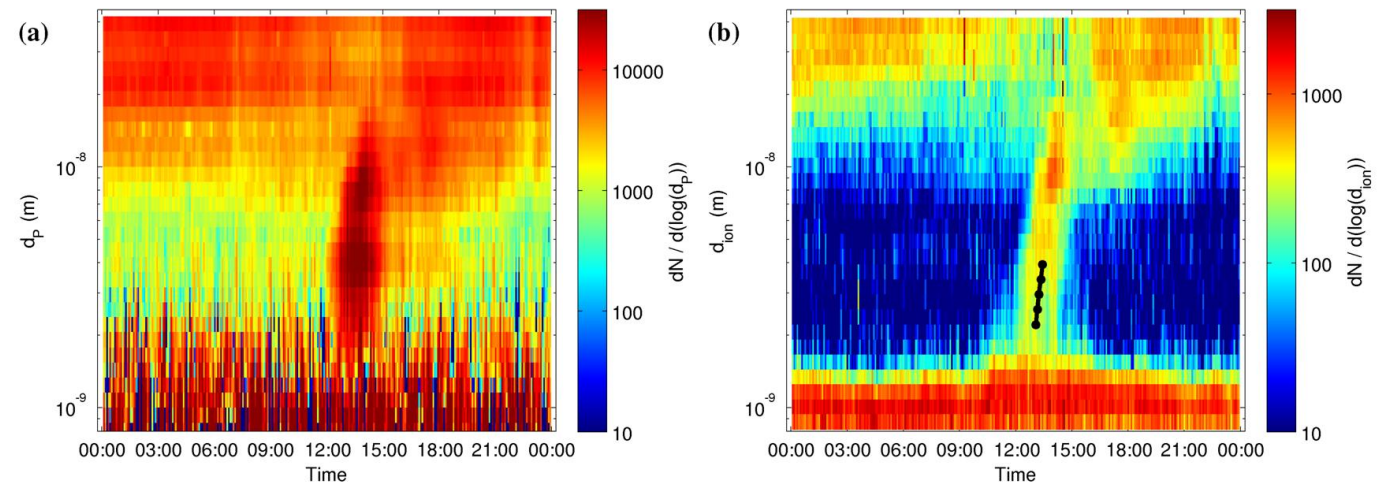

Fig. 2. Nucleation event recorded with the NAIS in Hohenpeissenberg on 21 September 2008. Panel (a) presents the total particle size distribution as a function of time. Corresponding particle concentrations are shown in colour. From this day, the data points measured between 11:30 and 14:50 were used in the analysis. Panel (b) shows the simultaneously measured size distributions of negative air ions. Growth rate between 2 and $4 \mathrm{~nm}$ is determined based on the maxima (black circles) of the normal distribution functions fitted in the concentration time series of size channels during the event. Note the different concentration scales in panels (a) and (b).

$\mathrm{GR}_{\mathrm{H}_{2} \mathrm{SO}_{4}}=\frac{\left[\mathrm{H}_{2} \mathrm{SO}_{4}\right]_{\mathrm{det}}}{C_{\mathrm{GR}=1, \mathrm{H}_{2} \mathrm{SO}_{4}}}$.

For the sulphuric acid concentration $\left[\mathrm{H}_{2} \mathrm{SO}_{4}\right]_{\text {det }}$ we used the one hour median of the measured concentrations recorded during the corresponding timeframe for determination of $\mathrm{GR}_{\text {det }}$.

\subsubsection{Estimated concentration of the low-volatility organic vapours}

The identity of vapours influencing the new particle formation, besides sulphuric acid, is not known so far. Therefore, we had to estimate their properties and concentration indirectly. We assumed that the vapours potentially participating in nucleation are the same as those causing the part of the condensational growth of the smallest freshly nucleated particles $\left(d_{\mathrm{p}}=2-4 \mathrm{~nm}\right)$, which cannot be explained by sulphuric acid. Although no clear evidence of the composition of these vapours is available, we assumed that they are of organic origin (e.g. Kulmala et al., 2004b; Riipinen et al., 2009). The growth rate related to the condensation of these vapours was calculated from the previously described growth rates as the difference between the observed growth rate and that due to sulphuric acid condensation, i.e.

$\mathrm{GR}_{\mathrm{org}}=\mathrm{GR}_{\mathrm{det}}-\mathrm{GR}_{\mathrm{H}_{2} \mathrm{SO}_{4}}$,

where $\mathrm{GR}_{\text {det }}$ refers to the observed growth rate. We considered the growth due to these vapours simply as a condensation process. This is justified, because the surface processes related to organic vapour uptake are apparently significant only for particles larger than $4 \mathrm{~nm}$ (Wang et al., 2010).

We approximated the properties of the organic vapour species with those of monoterpene oxidation products, with the chemical formula $\mathrm{C}_{10} \mathrm{H}_{16} \mathrm{O}_{2}$ (Taipale et al., 2008). The corresponding molecule mass is $168 \mathrm{amu}$, and for the density we assumed a value of $1200 \mathrm{~kg} \mathrm{~m}^{-3}$ (Kannosto et al., 2008; Hallquist et al., 2009). With these estimations, using Eq. (1), we calculated the organic vapour concentration $C_{\mathrm{GR}=1 \text {, org }}$ leading to $1 \mathrm{~nm} \mathrm{~h}^{-1}$ growth, and further the organic vapour concentration needed to produce $\mathrm{GR}_{\text {org }}$ as

$[\text { org }]_{\mathrm{det}}=\mathrm{GR}_{\mathrm{org}} C_{\mathrm{GR}=1 \text {, org }}$.

As stated earlier, Eq. (1) gives the theoretical minimum of the vapour concentration needed for the $1 \mathrm{~nm} \mathrm{~h}^{-1}$ growth. Thus, the concentration calculated in Eq. (4) is the minimum concentration of low-volatility organic vapours needed for completing the observed growth rate.

With the above described method we could derive one value per day for the growth rate of the particles and, thereby, also for the concentration of condensing oxidized organic vapours. However, the concentration of oxidized organic vapours is expected to vary significantly during the day, due to the variation in both their source, the oxidation rate of precursor vapours, and their sink, condensation to ambient aerosol. Because the concentration of the precursor vapours could not be determined, we approximated the concentration of the oxidized organic vapours to be directly proportional to the concentration of the hydroxyl radical $(\mathrm{OH})$, and inversely proportional to the condensational sink CS (Kulmala et al., 2001). The oxidized organic vapours condensing on particles with $d_{\mathrm{p}}=2-4 \mathrm{~nm}$ were assumed to be produced via $\mathrm{OH}$ oxidation neglecting the other important daytime oxidation pathway, ozonolysis (Hao et al., 2009; Kulmala et al., 2004b). Even if this assumption did not hold exactly, the ozone concentration does not have as strong a diurnal variation as the $\mathrm{OH}$ concentration and, thus, would not have as drastic an impact on the diurnal cycle of [org] as would the hydroxyl radical concentration. Since the measured $\mathrm{OH}$ concentration was not available from all the measurement sites, we approximated the diurnal variation of $\mathrm{OH}$ 
concentration by the variation observed in global radiation. This is justified, since the main atmospheric pathway in the production of OH-radical is the photolysis of ozone by UV-B radiation (Rohrer and Berresheim, 2006), which at the same time correlates well with the global radiation. Hence, the estimated concentration of the oxidized organic vapours is written as

$$
[\operatorname{org}]=[\operatorname{org}](t)=[\operatorname{org}]_{\operatorname{det}} \frac{\operatorname{GlobRad}(t) / \mathrm{GlobRad}_{\text {det }}}{\mathrm{CS}(t) / \mathrm{CS}_{\mathrm{det}}},
$$

where CS refers to the condensational sink for organic vapours, calculated from the DMPS/SMPS data by using the dry size of the particles. The indices "det" refer to the one hour median values during the timeframe of determination of the growth rate. Using this scaled organic vapour concentration, we calculated the time dependent growth rate of the particles

$\mathrm{GR}_{2-4}=\frac{\left[\mathrm{H}_{2} \mathrm{SO}_{4}\right]}{C_{\mathrm{GR}=1, \mathrm{H}_{2} \mathrm{SO}_{4}}}+\frac{[\mathrm{org}]}{C_{\mathrm{GR}=1, \text { org }}}$.

\subsubsection{Particle formation rate $J_{2}$}

When measuring on the total particle mode, the NAIS detects not only the neutral particles, but also the natural external ions of the same size. Typically the NAIS detects high total concentrations of particles below $2 \mathrm{~nm}$ size (e.g. Fig. 2a). A fraction of these particles can be real atmospheric clusters (Kulmala et al., 2007) which, however, can not be readily distinguished from the ions produced in the corona charger of the instrument (Asmi et al., 2009). Due to this uncertainty, the total particle concentrations were only calculated down to $2 \mathrm{~nm}$ diameter limit. However, this diameter is adequate, because the diameter of the stable particles formed in nucleation is assumed to be between 1 and $2 \mathrm{~nm}$ (e.g. Kulmala et al., 2007; Nieminen et al., 2009; Sipilä et al., 2010).

The particle formation rate $\left(J_{2}^{\text {tot }}\right.$, where the index 2 refers to the formation of particles with $d_{\mathrm{p}}=2 \mathrm{~nm}$, and "tot" to total as both neutral and charged) was calculated with the method presented by Riipinen et al. (2007) and Kulmala et al. (2007), by using the concentration $N_{2-4}^{\text {tot }}$ of 2 to $4 \mathrm{~nm}$ particles measured with the NAIS, and the time derivative $d N_{2-4}^{\text {tot }} / d t$ of this concentration in the equation

$J_{2}^{\mathrm{tot}}=\frac{d N_{2-4}^{\mathrm{tot}}}{d t}+\frac{\mathrm{GR}_{2-4} N_{2-4}^{\mathrm{tot}}}{4 \mathrm{~nm}-2 \mathrm{~nm}}+\mathrm{CoagS}_{3} N_{2-4}^{\mathrm{tot}}$,

where $\mathrm{CoagS}_{3}$ is the coagulational sink (Kulmala et al., 2001) for particles with $d_{\mathrm{p}}=3 \mathrm{~nm}$ (close to the geometric mean of the size bin $2-4 \mathrm{~nm}$ ), calculated from the DMPS/SMPS data. On the right-hand side of Eq. (7), the first term represents the observed change of the concentration, the second term is the growth out of the specified size range and the third term describes the coagulational scavenging. In calculating $\mathrm{CoagS}_{3}$, we used the dry size of the particles.

\subsubsection{Charged and neutral particle formation rates}

The formation rates of positively and negatively charged particles with diameter $d_{\mathrm{p}}=2 \mathrm{~nm}\left(J_{2}^{+}\right.$and $J_{2}^{-}$, respectively $)$were calculated from the ion size distributions measured with the NAIS almost similarly to the total particle formation rate $J_{2}^{\text {tot }}$. However, two additional terms appear in the equation: a sink of ions with $d_{\mathrm{p}}=2-4 \mathrm{~nm}$ caused by their recombination with the ions of the opposite polarity, and a source due to the charging of neutral particles via coagulation with smaller ions. Thus, the formation rate of positively charged particles may be written as (Manninen et al., 2009)

$$
\begin{aligned}
J_{2}^{+} & =\frac{d N_{2-4}^{+}}{d t}+\frac{\mathrm{GR}_{2-4} N_{2-4}^{+}}{4 \mathrm{~nm}-2 \mathrm{~nm}}+\mathrm{CoagS}_{3} N_{2-4}^{+} \\
& +\alpha \cdot N_{2-4}^{+} N_{<4}^{-}-\beta \cdot N_{2-4}^{\text {tot }} N_{<2}^{+} .
\end{aligned}
$$

The formation rate of negatively charged particles $J_{2}^{-}$is calculated equally but using the opposite polarities. In Eq. (8) $N_{<d}$ denotes the concentration of ions with a diameter smaller than $d \mathrm{~nm}, \alpha=1.6 \times 10^{-6} \mathrm{~cm}^{3} \mathrm{~s}^{-1}$ is the recombination coefficient (Israël, 1970), and $\beta=1.0 \times 10^{-8} \mathrm{~cm}^{3} \mathrm{~s}^{-1}$ is the ion-neutral particle attachment coefficient (Tammet and Kulmala, 2005).

In order to examine the neutral fraction of $J_{2}^{\text {tot }}$, we subtracted the ion formation rates, and achieved

$J_{2}=J_{2}^{\mathrm{tot}}-J_{2}^{+}-J_{2}^{-}$.

We also calculated the recombination rate $\left(J_{\text {rec }}\right)$ producing neutral particles with $2-4 \mathrm{~nm}$ size. This was done by summing the products of the concentrations of those opposite polarity ions that would, colliding with each other, produce a particle with $d_{\mathrm{p}}=2-4 \mathrm{~nm}$, and multiplying this sum with the recombination coefficient $\alpha$. This method is more precisely described by Manninen et al. (2009). The recombination coefficient $\alpha$ describes the collision rate of opposite polarity ions and is, thus, the maximum rate coefficient for the production of stable neutral particles via recombination. There is no evidence and, thus, no reason to believe that the recombination product would still be stable when the electrical forces holding each of the charged particles together vanish. Because we do not know how large a fraction of the recombined ion pairs affects our measured $J_{2}$, we, thereby, did not subtract $J_{\text {rec }}$ in the calculation of the neutral particle formation rate $J_{2}$. Instead, the values of $J_{\text {rec }}$ were used in order to investigate which fraction of $J_{2}$ could be explained by the recombination of ions.

The particle formation rate data were filtered with a parabolic differentiation algorithm provided by the Matlab programme (with a window size of 3 data points, i.e. $30 \mathrm{~min}$ ), in order to reduce the fluctuations in $J_{2}$ data resulting from the noise in the calculation of the derivative $d N_{2-4} / d t$. Finally, the particle formation rate data was interpolated to the 10 min time steps of the sulphuric acid concentration data. 


\subsubsection{On the uncertainties of $\mathrm{N}_{2-4}$ measured with the NAIS}

We do accept the inaccuracy of the NAIS, when measuring the concentrations $N_{<3}$ of neutral particles with diameters below $3 \mathrm{~nm}$ (Asmi et al., 2009). This inaccuracy arises mainly from the charger ions, some fraction of which is detected as neutral particles with diameters below $3 \mathrm{~nm}$. However, as Asmi et al. (2009) state, this relative inaccuracy decreases when the ambient $N_{<3}$ is high, which is the case in all our analysed data points measured during the nucleation events. If the charger ions did affect the observed $N_{2-4}$, their effect on $J_{2}^{\text {tot }}$ would be most significant, when both actual $N_{2-4}$ and its time derivative are relatively small, i.e., in the data points with the smallest $J_{2}^{\text {tot }}$ (see Eq. 7). This effect would cause a slight overestimation of $J_{2}^{\text {tot }}$ in these data points.

\subsection{The studied nucleation mechanisms}

We investigated the models of two existing nucleation theories, the activation and kinetic theories, and six more or less new suggestions for neutral nucleation mechanisms. According to the activation theory, the sulphuric acid molecules activate the pre-existing neutral clusters with $d_{\mathrm{p}}<2 \mathrm{~nm}$ to further growth (Kulmala et al., 2006). Thereby, the number of activated clusters (i.e., formed particles) is, when a steady state nucleation rate is assumed, linearly connected to the sulphuric acid concentration

$J=A\left[\mathrm{H}_{2} \mathrm{SO}_{4}\right]$,

where $A$ is the activation coefficient.

Kinetic theory (McMurry and Friedlander, 1979) assumes homogenous homomolecular nucleation to occur between two sulphuric acid molecules as in gas kinetic theory and, thus, the nucleation rate is connected to the squared sulphuric acid concentration

$J=K\left[\mathrm{H}_{2} \mathrm{SO}_{4}\right]^{2}$.

Here the kinetic coefficient $K$ is not only the reaction rate coefficient, but includes both the collision frequency and the probability of formation of a stable particle after the collision (Weber et al., 1997; Sihto et al., 2006).

In addition to previous nucleation theories, also the thermodynamical models connecting $J$ with sulphuric acid to powers larger than two were briefly examined by looking into the coupling between $J$ and $\left[\mathrm{H}_{2} \mathrm{SO}_{4}\right]$ to powers 3 and 4 .

The activation and kinetic theories suggest that the nucleation rate is proportional to sulphuric acid concentration alone. The following mechanisms were derived assuming that the organic vapours participating in the initial growth of the nucleated particles are involved in the nucleation process itself, as well. The first studied mechanisms are equal to activation and kinetic theory, but the organic species is supposed to induce the nucleation instead of the sulphuric acid, either via cluster activation

$J=A_{\text {org }}[$ org $]$,

or by homogenous nucleation

$J=K_{\text {org }}[\operatorname{org}]^{2}$,

in which [org] stands for the concentration of the oxidized organic vapours condensing on sub 4-nm particles.

If we assume that both sulphuric acid and organic vapour can activate the pre-existing unidentified clusters, we can write

$J=A_{\mathrm{s}}\left(\left[\mathrm{H}_{2} \mathrm{SO}_{4}\right]+[\mathrm{org}]\right)$.

The next proposed mechanism presumes either homogenous heteromolecular nucleation between sulphuric acid and organic vapour molecules, or one of the vapours activating the clusters composed around a molecule of the other vapour, resulting in

$J=K_{\text {het }}\left[\mathrm{H}_{2} \mathrm{SO}_{4}\right][\mathrm{org}]$.

If in addition to heteromolecular nucleation (Eq. 15) the homogenous homomolecular nucleation of sulphuric acid takes place, we have

$J=K_{\mathrm{SA}}\left(\left[\mathrm{H}_{2} \mathrm{SO}_{4}\right]^{2}+\left[\mathrm{H}_{2} \mathrm{SO}_{4}\right][\mathrm{org}]\right)$,

and, if also the organic vapours can nucleate homomolecularly,

$J=K_{\mathrm{s}}\left(\left[\mathrm{H}_{2} \mathrm{SO}_{4}\right]^{2}+\left[\mathrm{H}_{2} \mathrm{SO}_{4}\right][\mathrm{org}]+[\mathrm{org}]^{2}\right)$.

In order to make it easier for the reader to understand the previously introduced coefficients with several subscript indices, some clarification for the choice of the indices follows: all the coefficients $A$ refer to the activation of pre-existing clusters while coefficients $K$ refer to the homogenous (kinetic type) nucleation; coefficients with no indices refer to the previously presented theories taking into account only the sulphuric acid concentration, index "org" refers to activation/nucleation by organic vapours solely, "s" to the sum of vapours or vapour combinations, "het" is connected with heteromolecular homogenous nucleation, and "SA" with the homogenous nucleation of sulphuric acid with both of the available vapours.

The activation and kinetic theories (Eqs. 10-11) have been studied in several articles, such as Kulmala et al. (2006), Sihto et al. (2006), Riipinen et al. (2007) and Paasonen et al. (2009). Also the heteromolecular homogenous nucleation mechanism (Eq. 15) has been investigated in laboratory conditions by Metzger et al. (2010). The rest of the mechanisms presented above are, to our best knowledge, studied here for the first time. 


\subsubsection{Optimized separate nucleation coefficients}

In addition to the nucleation mechanisms described above (Eqs. 10-17), we studied those mechanisms in which more than one term exist (Eqs. 14, 16 and 17) with separated coefficients for each term. By introducing these separate nucleation coefficients, the Eqs. (14), (16) and (17) are written as

$J=A_{\mathrm{s} 1}\left[\mathrm{H}_{2} \mathrm{SO}_{4}\right]+A_{\mathrm{s} 2}[\mathrm{org}]$,

$J=K_{\mathrm{SA} 1}\left[\mathrm{H}_{2} \mathrm{SO}_{4}\right]^{2}+K_{\mathrm{SA} 2}\left[\mathrm{H}_{2} \mathrm{SO}_{4}\right][\mathrm{org}]$

and

$J=K_{\mathrm{s} 1}\left[\mathrm{H}_{2} \mathrm{SO}_{4}\right]^{2}+K_{\mathrm{s} 2}\left[\mathrm{H}_{2} \mathrm{SO}_{4}\right][\mathrm{org}]+K_{\mathrm{s} 3}[\mathrm{org}]^{2}$.

The coefficients above were evaluated by minimizing the sum of the squares of the differences between the observed and modelled nucleation rates in every data point.

Different coefficients for separate terms can be expected, because the chemical properties of the sulphuric acid molecule and low-volatility organic vapour molecules are expected to be different, which will lead to varying concentrations needed to achieve a given activation and homogenous nucleation rates. Actually, among the condensing organic vapour molecules, there may be several vapours with different chemical composition and physical properties, but in this study we have no way of doing more than to treat these organic vapours as a bulk.

\subsubsection{Comparison of the nucleation mechanism models}

The comparison between the models of the different nucleation mechanisms was carried out both for the whole dataset and site by site. Our comparison is based on the following criteria:

- The correlation coefficient $R$ between the logarithms of the observed (Eq. 9) and modelled neutral nucleation rates.

- The variation $V_{90 / 10}$, i.e., the ratio of 90 th and 10 th percentiles of the data point-specific ratio between the observed and modelled nucleation rates. For example, when determining the $V_{90 / 10}$ for the $\mathrm{H}_{2} \mathrm{SO}_{4}$ activation mechanism $J=A\left[\mathrm{H}_{2} \mathrm{SO}_{4}\right]$, we first calculate the ratio $J_{2} /\left[\mathrm{H}_{2} \mathrm{SO}_{4}\right]$ in every data point, and then the 90th and 10th percentiles of these ratios. The variation $V_{90 / 10}$ is simply the ratio of these percentiles. If the resulting variation was $V_{90 / 10}=10$, then $80 \%$ of the data pointspecific coefficients $A\left(=J_{2} /\left[\mathrm{H}_{2} \mathrm{SO}_{4}\right]\right)$ would be within one order of magnitude. Similarly, $V_{90 / 10}=100$ would mean two orders of magnitude difference between the 90th and 10th percentiles.

- The dependency between the logarithms of the observed and modelled nucleation rates, in order to approximate the slope connecting these logarithms. If the slope differs significantly from one, the physical reasoning behind the modelled mechanism does not hold. This is because the slope in logarithmic scale is equal to the exponent in the linear scale. If, for example, a slope of 0.5 appeared in figure $\log \left(J_{2}\right)$ vs. $\log \left(\left[\mathrm{H}_{2} \mathrm{SO}_{4}\right][\right.$ org $\left.]\right)$, it would suggest a connection between $J_{2}$ and $\left(\left[\mathrm{H}_{2} \mathrm{SO}_{4}\right][\mathrm{org}]\right)^{0.5}$, which does not follow from the reasoning given for Eq. (15) above. The slope was estimated visually instead of by means of linear fitting, because the commonly used linear least squares fitting should not be used when the relative error in both $\mathrm{x}$ - and $\mathrm{y}$-directions is significant and, for example, the bivariate fitting method presented by York et al. (2004) could not be used due to the lack of proper error estimates for each quantity.

Some notes must be made on these comparison methods. First of all, as the correlation coefficients $R$ are calculated for logarithmic values, the exponent of the vapour concentration does not have an effect on $R$, i.e., equal $R$ results for $J_{2} \sim\left[\mathrm{H}_{2} \mathrm{SO}_{4}\right]$ and $J_{2} \sim\left[\mathrm{H}_{2} \mathrm{SO}_{4}\right]^{2}$. On the contrary, the variation $V_{90 / 10}$ is sensible to the order of the gas concentration, not only giving smaller values when the exponent is correct, but also systematically giving larger values for the mechanisms involving second order vapour concentrations (exponent 2 and/or term $\left[\mathrm{H}_{2} \mathrm{SO}_{4}\right][$ org] $)$. This is logical, because the relative error $\Delta f / f$, e.g., for $f=\left[\mathrm{H}_{2} \mathrm{SO}_{4}\right]^{2}$ is twice as large as that for $f=\left[\mathrm{H}_{2} \mathrm{SO}_{4}\right]$, as can be demonstrated by simple calculations concerning the propagation of error. Furthermore, the larger inaccuracy of [org] compared to $\left[\mathrm{H}_{2} \mathrm{SO}_{4}\right]$ increases the $V_{90 / 10}$ values for the organic vapour related mechanisms. Thus, even though the values of $R$ and $V_{90 / 10}$ give us an understanding of the reliability of the different modelled nucleation mechanisms, a visual examination is crucial for determining the reasonability of the models.

\section{Results and discussion}

\subsection{Site specific vapour concentrations, growth and particle formation rates}

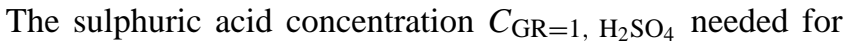
$1 \mathrm{~nm} \mathrm{~h}^{-1}$ growth varied between $1.1 \times 10^{7}$ and $1.3 \times 10^{7} \mathrm{~cm}^{-3}$ due to the differences in ambient temperature and relative humidity. The portion of growth rate related to sulphuric acid condensation from particle growth rate $\mathrm{GR}_{\text {det }}$ was, as expected, clearly dependent on the sulphuric acid concentration (Fig. 3).

For the organic vapour, we did not have hydrate distribution or density parameterizations available and, thus, using the oxidized monoterpene properties presented in Sect. 2.3.2 we determined a constant minimum concentration $C_{\mathrm{GR}=1, \text { org }}=9.4 \times 10^{6} \mathrm{~cm}^{-3}$ that would be required to produce a growth rate of $1 \mathrm{~nm} \mathrm{~h}^{-1}$ due to the organic vapour condensation. 
Table 1. Statistics of the new particle formation events at different measurement sites. The observed growth rates $\mathrm{GR}_{\mathrm{det}}$ are median values for all the events. The tabulated median values for sulphuric acid concentration $\left[\mathrm{H}_{2} \mathrm{SO}_{4}\right]$, low-volatility organic vapour concentration [org], neutral particle formation rate $J_{2}$ and ion formation rate $J_{2}^{\text {ion }}$ as a sum of $J_{2}^{+}$and $J_{2}^{-}$are calculated from the data points measured during the nucleation events.

\begin{tabular}{lllrrrrr}
\hline & $\begin{array}{l}\text { Analysed } \\
\text { events, \# }\end{array}$ & $\begin{array}{l}\text { Data from } \\
\text { months }\end{array}$ & $\begin{array}{r}\mathrm{GR}_{\mathrm{det}}, \\
(\mathrm{nm} / \mathrm{h})\end{array}$ & $\begin{array}{r}{\left[\mathrm{H}_{2} \mathrm{SO}_{4}\right],} \\
\left(10^{6} \mathrm{~cm}^{-3}\right)\end{array}$ & $\begin{array}{r}{[\mathrm{org}],} \\
\left(10^{6} \mathrm{~cm}^{-3}\right)\end{array}$ & $\begin{array}{r}J_{2}, \\
\left(\mathrm{~cm}^{-3} \mathrm{~s}^{-1}\right)\end{array}$ & $\begin{array}{r}J_{2}^{\text {ion }}, \\
\left(\mathrm{cm}^{-3} \mathrm{~s}^{-1}\right)\end{array}$ \\
\hline Hyytiälä & 10 & April-May & 3.3 & 1.1 & 16 & 1.9 & 0.041 \\
HPB & 15 & Full year & 4.8 & 2.3 & 48 & 2.3 & 0.094 \\
Melpitz & 8 & May & 4.2 & 18 & 16 & 9.4 & 0.036 \\
SPC & 3 & (June-)July & 9.5 & 16 & 63 & 13 & 0.20 \\
\hline
\end{tabular}

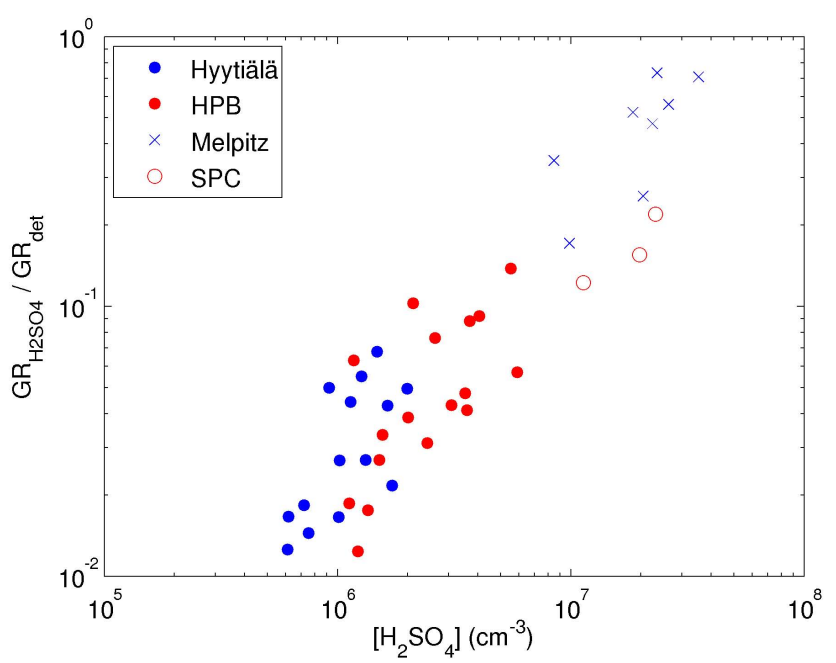

Fig. 3. The ratio between calculated growth rate due to sulphuric acid condensation and the growth rate determined from particle size distributions, as a function of sulphuric acid concentration at four measurement sites.

The median values of the observed growth rate, sulphuric acid concentration, calculated low-volatility organic vapour concentration, and neutral and charged particle formation rates for each measurement site are presented in Table 1 . It should be kept in mind that the median values for Hohenpeissenberg are calculated for nucleation events which were measured all year round, whereas at the other sites the measurements were carried out during the late spring or summer months only. Unfortunately, during these months (April-July) only two analysable nucleation events were recorded at Hohenpeissenberg (partly due to the use of DWD CIMS at the other measurement sites) and, thus, a detailed spring/summer comparison could not be carried out.

The median sulphuric acid concentration was approximately an order of magnitude higher in Melpitz and SPC $\left(\left[\mathrm{H}_{2} \mathrm{SO}_{4}\right] \sim 10^{7} \mathrm{~cm}^{-3}\right)$ than in Hyytiälä and HPB $\left(\left[\mathrm{H}_{2} \mathrm{SO}_{4}\right] \sim 10^{6} \mathrm{~cm}^{-3}\right)$, whereas the estimated organic vapour concentration was higher in HPB and
SPC ([org $\left.]>4 \times 10^{7} \mathrm{~cm}^{-3}\right)$ than in Hyytiälä and Melpitz ( $[\mathrm{org}]<2 \times 10^{7} \mathrm{~cm}^{-3}$ ). In Hyytiälä and Hohenpeissenberg, the sulphuric acid induced portion from the total growth did not exceed 14\%, whereas in Melpitz the sulphuric acid concentration could explain from up to $74 \%$ of the observed growth.

The median neutral particle formation rates $J_{2}$ were about five times higher in SPC and Melpitz than in Hohenpeissenberg and Hyytiälä $\left(13,9.4,2.3\right.$ and $1.9 \mathrm{~m}^{-3} \mathrm{~s}^{-1}$, respectively). In the whole dataset, $J_{2}$ varied between 0.01 and $80 \mathrm{~m}^{-3} \mathrm{~s}^{-1}$.

We also calculated the maximum recombination rate $J_{\text {rec }}$ producing particles with diameters from 2 to $4 \mathrm{~nm}$. The median ratio $J_{\text {rec }} / J_{2}$ was 0.015 . This ratio exceeded 0.1 in $9 \%$ of the data points, and exceeded 0.2 only in $4 \%$ of the data points. Thus, the recombination of ions does not explain so large a portion of the neutral particle formation rate that the connection between $J_{2}$ and vapour concentrations would be drastically affected by it.

\subsection{The couplings between $J_{2}$ and the vapour concentrations}

The correlation coefficients $R$ between the logarithms of the observed and modelled neutral particle formation rates $J_{2}$ are presented in Table 2, as well as the variations $V_{90 / 10}$, i.e., the ratios of the 90th and 10th percentile values of the ratios between observed and modelled nucleation rate in each data point. Also the correlation and variation achieved by means of a linear coupling between $J_{2}$ and GR is presented for comparison (see Sect. 3.3.3).

\subsubsection{Sulphuric acid nucleation}

The correlation between the neutral particle formation rate $J_{2}$ and sulphuric acid concentration $\left[\mathrm{H}_{2} \mathrm{SO}_{4}\right]$ was quite strong in Hyytiälä, Melpitz and SPC (correlation coefficients $R$ of $0.58,0.68$ and 0.58 , respectively) and when the data of all the sites were considered $(R=0.65)$. However, in Hohenpeissenberg the correlation between $J_{2}$ and $\left[\mathrm{H}_{2} \mathrm{SO}_{4}\right]$ was weak ( $R=0.17) . \quad J_{2}$ as a function of $\left[\mathrm{H}_{2} \mathrm{SO}_{4}\right]$ is presented for all 
Table 2. Correlation coefficients $R$ and variations $V_{90 / 10}$ achieved with all the tested nucleation mechanism models. The nucleation coefficient values for Eqs. (18) to (20) corresponding to the tabulated values of $R$ and $V_{90 / 10}$ are presented in Table 3.

\begin{tabular}{|c|c|c|c|c|c|c|c|c|c|c|c|}
\hline $\begin{array}{l}\text { Nucleation mechanism } \\
\text { Measurement site } \\
\text { (number of data points) }\end{array}$ & & \multicolumn{5}{|c|}{ Correlation coefficient $R$} & \multicolumn{5}{|c|}{ Variation $V_{90 / 10}$} \\
\hline$J_{2}=K\left[\mathrm{H}_{2} \mathrm{SO}_{4}\right]^{2}$ & (11) & 0.65 & 0.58 & 0.17 & 0.68 & 0.58 & 174 & 18 & 99 & 12 & 7 \\
\hline$J_{2}=A_{\text {org }}[$ org $]$ & $(12)$ & 0.17 & 0.29 & 0.61 & -0.23 & 0.07 & 39 & 23 & 8 & 40 & 11 \\
\hline$J_{2}=K_{\text {org }}[\text { org }]^{2}$ & (13) & 0.17 & 0.29 & 0.61 & -0.23 & 0.07 & 202 & 174 & 17 & 196 & 19 \\
\hline$J_{2}=K_{\mathrm{SA}}\left(\left[\mathrm{H}_{2} \mathrm{SO}_{4}\right]^{2}+\left[\mathrm{H}_{2} \mathrm{SO}_{4}\right][\mathrm{org}]\right)$ & (16) & 0.67 & 0.53 & 0.46 & 0.66 & 0.52 & 30 & 17 & 33 & 8 & 7 \\
\hline$J_{2}=K_{\mathrm{S}}\left(\left[\mathrm{H}_{2} \mathrm{SO}_{4}\right]^{2}+\left[\mathrm{H}_{2} \mathrm{SO}_{4}\right][\mathrm{org}]+[\mathrm{org}]^{2}\right)$ & (17) & 0.47 & 0.32 & 0.61 & 0.61 & 0.19 & 71 & 136 & 17 & 11 & 13 \\
\hline$J_{2}=A_{\mathrm{s} 1}\left[\mathrm{H}_{2} \mathrm{SO}_{4}\right]+A_{\mathrm{s} 2}[\mathrm{org}]$ & (18) & 0.70 & 0.55 & 0.51 & 0.68 & 0.57 & 10 & 8 & 11 & 7 & 6 \\
\hline$J_{2}=K_{\mathrm{SA} 1}\left[\mathrm{H}_{2} \mathrm{SO}_{4}\right]^{2}+K_{\mathrm{SA} 2}\left[\mathrm{H}_{2} \mathrm{SO}_{4}\right][\mathrm{org}]$ & (19) & 0.64 & 0.58 & 0.46 & 0.58 & 0.50 & 28 & 20 & 31 & 8 & 8 \\
\hline
\end{tabular}

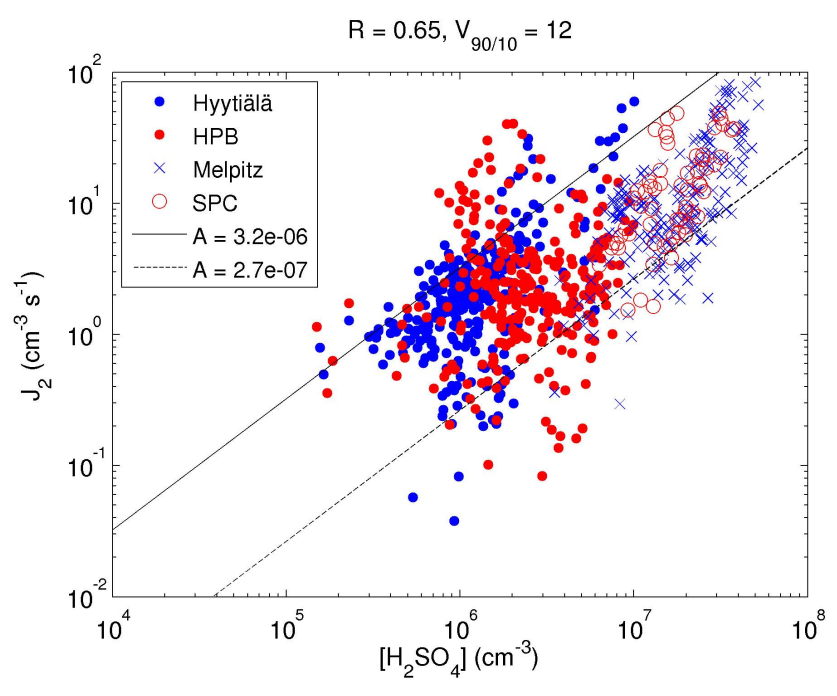

Fig. 4. Neutral particle formation rate $J_{2}$ as a function of sulphuric acid concentration. The lines present the 90th and 10th percentile values of the activation coefficient $A$ (Eq. 10), the values of which are given in units $\left(\mathrm{s}^{-1}\right)$.

the measurement sites in Fig. 4. The 90th and 10th percentile values for coefficient $A$ are shown in the figure, as well.

In Fig. 4, all the data points are quite well located in the same range of coefficients $A$. However, the data points of the individual sites seem to request a slope larger than one (slope one equals to the slope of the percentile lines in figures). This is illustrated more clearly in Fig. 5, where the formation rate at every site is presented separately as a function of the squared sulphuric acid concentration. In Fig. 5, the data
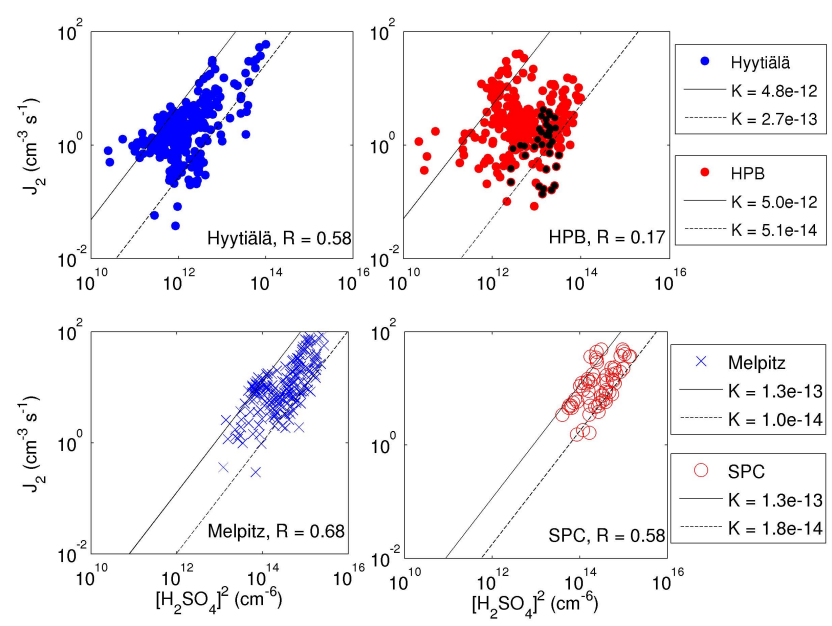

Fig. 5. Neutral particle formation rate $J_{2}$ as a function of squared sulphuric acid concentration separately for each measurement site. In the Hohenpeissenberg plot (upper right) the black points indicate the data recorded between April and July, whereas at the other sites all the data are from these months. The lines present the site-specific 90th and 10th percentile values of the kinetic coefficient $K$ (Eq. 11), the values of which are presented in units $\left(\mathrm{cm}^{3} \mathrm{~s}^{-1}\right)$ on the right hand side.

recorded at HPB between April and July are marked separately. Even though these data points are from only two nucleation event days, they suggest that in HPB the nucleation rate cannot be satisfactorily described by means of models based on sulphuric acid alone even during the spring and summer months. 

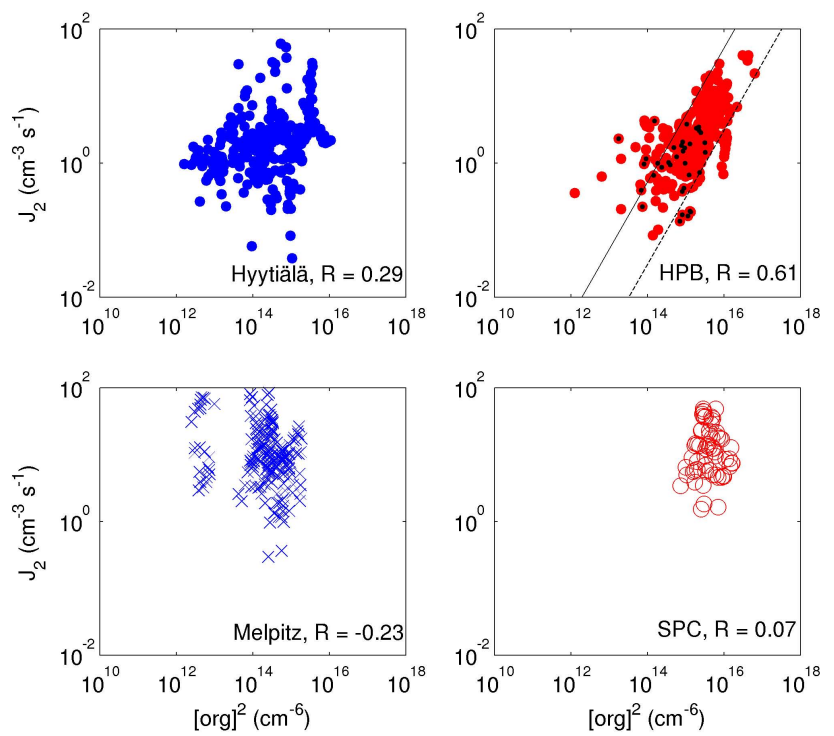

Fig. 6. Neutral particle formation rate $J_{2}$ as a function of squared low-volatility organic vapour concentration separately at the measurement sites. In the Hohenpeissenberg plot (upper right) the black points indicate the data recorded between April and July, whereas at the other sites all the data are from these months. The lines in Hohenpeissenberg plot present the site-specific 90th and 10th percentile values of the coefficient $K_{\text {org }}$ (Eq. 13), $5.1 \times 10^{-15}$ and $3.1 \times 10^{-16} \mathrm{~cm}^{3} \mathrm{~s}^{-1}$, respectively.

Even though Fig. 5 clearly shows that $J_{2}$ is connected to $\left[\mathrm{H}_{2} \mathrm{SO}_{4}\right]^{2}$ in Hyytiälä, Melpitz and SPC, the values for coefficients $K$ are from one to two orders of magnitude higher in Hyytiälä and HPB than in Melpitz and SPC. This leads to a large variation, $V_{90 / 10}=174$, for the entire dataset (see Table 2). Also the $V_{90 / 10}$ values for the individual sites are higher than those resulting from the activation mechanism. However, as these site-specific variations are not more than twice as high as those resulting from the activation mechanism, the increase may result from the propagation of uncertainty when the sulphuric acid concentration is squared, as mentioned in Sect. 2.4.2. On the contrary, when increasing the power of sulphuric acid concentration to 3 or 4 , as suggested by the thermodynamical models, all the site-specific values as well as the inter-site value of $V_{90 / 10}$ increased to a greater extent than can be explained by the propagation of uncertainty (values not presented). The correlations and variations are discussed in more details in Sect. 3.3.

\subsubsection{Organic vapour nucleation}

In Hohenpeissenberg the neutral new particle formation rate $J_{2}$ correlates well with the low-volatility organic vapour concentration [org] ${ }^{2}, R=0.61$ (Fig. 6), instead of with $\left[\mathrm{H}_{2} \mathrm{SO}_{4}\right]^{2}$. In Hyytiälä this correlation is clearly weaker $(R=0.29)$ and it is non-existing or even negative in SPC and Melpitz.

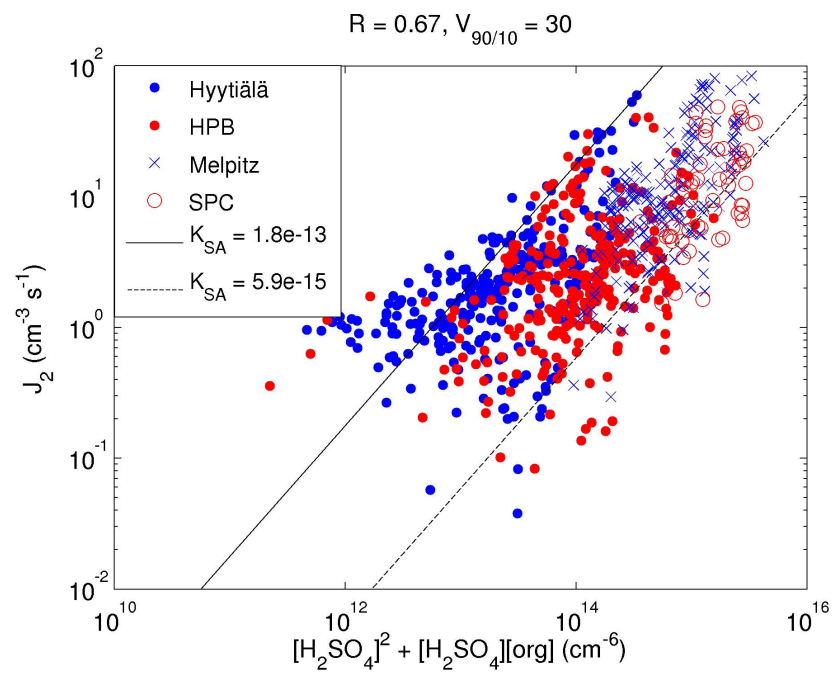

Fig. 7. Neutral particle formation rate $J_{2}$ as a function of the sum of the squared sulphuric acid concentration and the product of sulphuric acid and organic vapour concentrations. The lines present the 90th and 10th percentile values of the coefficient $K_{\mathrm{SA}}$ (Eq. 16), the values of which are presented in units $\left(\mathrm{cm}^{3} \mathrm{~s}^{-1}\right)$.

\subsubsection{Nucleation of both sulphuric acid and organic vapour}

The correlation between $J_{2}$ and the model for homogenous heteromolecular nucleation (Eq. 15) was fairly strong, $R=0.59$, for the entire dataset (see Table 2). However, the best correlation coefficient, $R=0.67$, for the models using a single nucleation coefficient was achieved with Eq. (16) (Fig. 7), suggesting that both homogenous heteromolecular and homogenous homomolecular nucleation of sulphuric acid occur. This model also resulted in the smallest variation $\left(V_{90 / 10}=30\right)$ amongst the mechanisms related to second order gas concentrations and a single nucleation coefficient, when all the data was considered, and smaller site-specific $V_{90 / 10}$ values for Hyytiälä, Melpitz and SPC than those resulting from the model for the heteromolecular nucleation alone (Eq. 15). Regardless of the good correlation, the slope for the whole dataset in Fig. 7 seems to be smaller than one.

\subsubsection{The optimized nucleation coefficients}

The presented optimized nucleation coefficients (Table 3), and the variations and correlation coefficients (Table 2) resulting from their insertion into Eqs. (18) to (20) were obtained by minimizing the sum of squares of the differences in observed and modelled new particle formation rates. Only the parameters optimized for the whole dataset, all measurement sites together, are presented here.

The modelled mechanism connecting $J$ linearly with the sum of the vapour concentrations (Eqs. 14 and 18) resulted in a remarkably larger correlation coefficient and smaller 
Table 3. Values of the optimized separate nucleation coefficients, with the corresponding correlation coefficients $R$ and variations $V_{90 / 10}$.

\begin{tabular}{|c|c|c|c|c|c|c|c|c|}
\hline Nucleation mechanism & & $\begin{array}{l}K_{\mathrm{s} 1} \text { or } K_{\mathrm{SA} 1} \\
\left(10^{-14} \mathrm{~cm}^{3} \mathrm{~s}^{-1}\right)\end{array}$ & $\begin{array}{l}K_{\mathrm{s} 2} \text { or } K_{\mathrm{SA} 2} \\
\left(10^{-14} \mathrm{~cm}^{3} \mathrm{~s}^{-1}\right)\end{array}$ & $\begin{array}{l}K_{\mathrm{s} 3} \\
\left(10^{-14} \mathrm{~cm}^{3} \mathrm{~s}^{-1}\right)\end{array}$ & $\begin{array}{l}A_{\mathrm{s} 1} \\
\left(10^{-7} \mathrm{~s}^{-1}\right)\end{array}$ & $\begin{array}{l}A_{\mathrm{s} 2} \\
\left(10^{-7} \mathrm{~s}^{-1}\right)\end{array}$ & $R$ & $V_{90 / 10}$ \\
\hline$J_{2}=A_{\mathrm{s} 1}\left[\mathrm{H}_{2} \mathrm{SO}_{4}\right]+A_{\mathrm{s} 2}[\mathrm{org}]$ & (Eq. 18) & - & - & - & 6.1 & 0.39 & 0.70 & 10 \\
\hline$J_{2}=K_{\mathrm{SA} 1}\left[\mathrm{H}_{2} \mathrm{SO}_{4}\right]^{2}+K_{\mathrm{SA} 2}\left[\mathrm{H}_{2} \mathrm{SO}_{4}\right][\mathrm{org}]$ & (19) & 1.1 & 3.2 & - & - & - & 0.64 & 28 \\
\hline$J_{2}=K_{\mathrm{s} 1}\left[\mathrm{H}_{2} \mathrm{SO}_{4}\right]^{2}+K_{\mathrm{s} 2}\left[\mathrm{H}_{2} \mathrm{SO}_{4}\right][$ org $]+K_{\mathrm{s} 3}[\mathrm{org}]^{2}$ & (20) & 1.4 & 2.6 & 0.037 & - & - & 0.65 & 26 \\
\hline
\end{tabular}

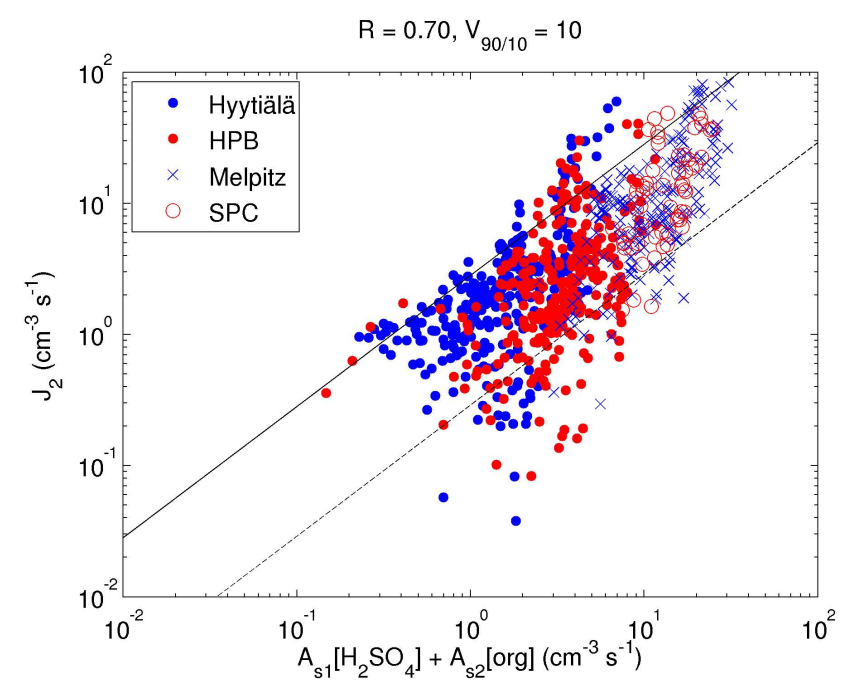

Fig. 8. Neutral particle formation rate $J_{2}$ as a function of the sum of sulphuric acid and low-volatility organic vapour concentrations multiplied with separate nucleation coefficients $A_{\mathrm{s} 1}=5.8 \times 10^{-7}$ and $A_{\mathrm{s} 2}=5.4 \times 10^{-8} \mathrm{~s}^{-1}$. The lines present the 90th (solid) and 10th (dashed) percentile values of the ratio between the observed $J_{2}$ and the rate modelled with Eq. (18).

variation with separated coefficients $A_{\mathrm{s} 1}$ and $A_{\mathrm{s} 2}$ than with $A_{\mathrm{s}}$ alone (Table 2). With this model, by using values $A_{\mathrm{s} 1}=6.1 \times 10^{-7}$ and $A_{\mathrm{s} 2}=3.9 \times 10^{-8} \mathrm{~s}^{-1}$, the highest correlation coefficient and smallest variation $\left(R=0.70, V_{90 / 10}=10\right)$ for the whole dataset were achieved. However, even with these coefficients, the site-specific datasets are better described with slope values over one (Fig. 8).

The optimization of the separated nucleation coefficients in Eq. (19), modelling homogenous nucleation of sulphuric acid both homomolecularly and heteromolecularly, resulted in values $K_{\mathrm{SA} 1}=1.1 \times 10^{-14}$ and $K_{\mathrm{SA} 2}=3.2 \times 10^{-14} \mathrm{~cm}^{3} \mathrm{~s}^{-1}$. These coefficients lead to a slight decrease of both the correlation coefficient and the variation, compared to those achieved with a single nucleation coefficient (Eq. 16). The decrease of $R$ from 0.67 to 0.64 may result from the increasing uncertainty when the term including [org] becomes more significant (as $K_{\mathrm{SA} 2}>K_{\mathrm{SA} 1}$ ). The introduction of a term describing the homogenous homomolecular nucleation of the organic vapours (Eq. 20 with $K_{\mathrm{s} 1}=1.4 \times 10^{-14}$, $K_{\mathrm{s} 2}=2.6 \times 10^{-14}$ and $K_{\mathrm{s} 3}=3.7 \times 10^{-16} \mathrm{~cm}^{3} \mathrm{~s}^{-1}$ ) had only a

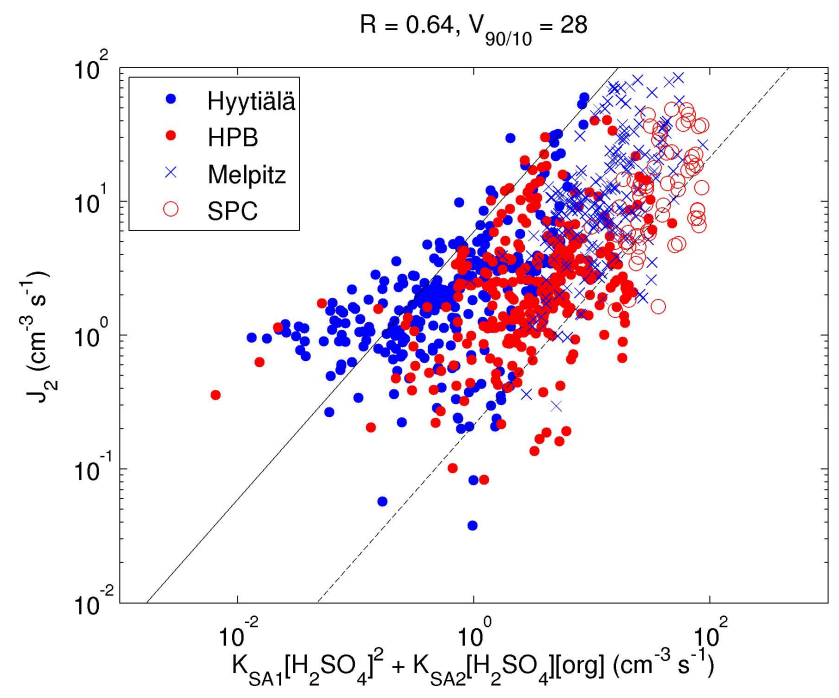

Fig. 9. Neutral particle formation rate $J_{2}$ as a function of the sum of the squared sulphuric acid concentration and the product of sulphuric acid and organic vapour concentrations, terms multiplied with separate nucleation coefficients $K_{\mathrm{SA} 1}=9.5 \times 10^{-15}$ and $K_{\mathrm{SA} 2}=4.6 \times 10^{-14} \mathrm{~cm}^{3} \mathrm{~s}^{-1}$. The lines present the 90 th (solid) and 10 th (dashed) percentile values of the ratio between the observed $J_{2}$ and the rate modelled with Eq. (19).

minor influence on the correlation and variation resulting from Eq. (19). Also the figures depicted for Eq. (19) (Fig. 9) and Eq. (20) (figure not shown) were very similar. Nevertheless, both of these models brought the slope for the entire dataset closer to one than Eq. (16), as can be seen by comparing Figs. 7 and 9. Furthermore, compared to Fig. 8 presenting $J_{2}$ vs. the sum of the first order gas concentrations, the data points of the individual sites agree much better with the slope one in Fig. 9.

\subsubsection{Values of the derived nucleation coefficients}

The mean, median and percentile values (10th, 25th, 75th and 90th) of the nucleation coefficients for the whole dataset, as well as the site specific medians, are presented in Table 4 . We would like to emphasize that the presented coefficient values should be considered as estimative, mostly due to the uncertainties in the determination of the growth rate. Thus, the uncertainties are noticeable especially in the 
Table 4. Mean, median and percentile (10th, 25th, 75th and 90th) values of the nucleation coefficients for the whole dataset, and median values for separate measurement sites. The mean, median and percentile values of the ratios between the observed and modelled nucleation rates are presented related to the mechanisms including separate nucleation coefficients (the values of which are presented in Table 3).

\begin{tabular}{|c|c|c|c|c|c|c|c|c|c|c|c|}
\hline \multirow[t]{2}{*}{ Nucleation coefficient } & & \multirow[t]{2}{*}{ Mean } & \multirow[t]{2}{*}{ Median } & \multicolumn{4}{|c|}{ Percentiles } & \multicolumn{4}{|c|}{ Site specific medians } \\
\hline & & & & 10th & 25 th & 75th & 90th & HYY & HPB & MEL & SPC \\
\hline$A\left(10^{-7} \mathrm{~s}^{-1}\right)$ & (Eq. 10) & 17 & 10 & 2.7 & 4.7 & 20 & 32 & 19 & 8.6 & 6.0 & 7.4 \\
\hline$K\left(10^{-14} \mathrm{~cm}^{3} \mathrm{~s}^{-1}\right)$ & (11) & 140 & 28 & 2.1 & 5.4 & 140 & 360 & 140 & 33 & 3.3 & 3.9 \\
\hline$A_{\text {org }}\left(10^{-7} \mathrm{~s}^{-1}\right)$ & (12) & 7.0 & 1.3 & 0.25 & 0.51 & 3.5 & 9.9 & 1.3 & 0.52 & 6.1 & 2.0 \\
\hline$K_{\text {org }}\left(10^{-14} \mathrm{~cm}^{3} \mathrm{~s}^{-1}\right)$ & (13) & 21 & 0.44 & 0.054 & 0.11 & 2.3 & 11 & 0.74 & 0.11 & 3.9 & 0.36 \\
\hline$A_{\mathrm{S}}\left(10^{-7} \mathrm{~s}^{-1}\right)$ & (14) & 2.0 & 1.1 & 0.24 & 0.46 & 2.5 & 4.8 & 1.1 & 0.48 & 2.8 & 1.6 \\
\hline$K_{\text {het }}\left(10^{-14} \mathrm{~cm}^{3} \mathrm{~s}^{-1}\right)$ & (15) & 11 & 4.1 & 0.73 & 1.6 & 11 & 24 & 11 & 2.0 & 4.2 & 1.1 \\
\hline$K_{\mathrm{SA}}\left(10^{-14} \mathrm{~cm}^{3} \mathrm{~s}^{-1}\right)$ & (16) & 8.3 & 2.6 & 0.59 & 1.2 & 8.8 & 18 & 10 & 1.9 & 1.6 & 0.88 \\
\hline$K_{\mathrm{s}}\left(10^{-14} \mathrm{~cm}^{3} \mathrm{~s}^{-1}\right)$ & (17) & 1.5 & 0.37 & 0.050 & 0.10 & 1.2 & 3.5 & 0.69 & 0.10 & 1.1 & 0.23 \\
\hline$\frac{J_{2}}{A_{\mathrm{s} 1}\left[\mathrm{H}_{2} \mathrm{SO}_{4}\right]+A_{\mathrm{s} 2}[\text { org }]}$ & (18) & 1.3 & 1.0 & 0.29 & 0.51 & 1.7 & 2.8 & 1.4 & 0.65 & 0.92 & 0.98 \\
\hline$\frac{J_{2}}{K_{\mathrm{SA} 1}\left[\mathrm{H}_{2} \mathrm{SO}_{4}\right]^{2}+K_{\mathrm{SA}_{2}\left[\mathrm{H}_{2} \mathrm{SO}_{4}\right][\mathrm{org}]}}$ & (19) & 2.9 & 1.0 & 0.21 & 0.44 & 3.0 & 5.9 & 3.4 & 0.62 & 0.87 & 0.32 \\
\hline$\frac{J_{2}}{K_{\mathrm{s} 1}\left[\mathrm{H}_{2} \mathrm{SO}_{4}\right]^{2}+K_{\mathrm{s} 2}\left[\mathrm{H}_{2} \mathrm{SO}_{4}\right][\mathrm{org}]+K_{\mathrm{s} 3}[\mathrm{org}]^{2}}$ & $(20)$ & 3.0 & 1.0 & 0.23 & 0.44 & 2.8 & 5.8 & 3.3 & 0.56 & 0.87 & 0.36 \\
\hline
\end{tabular}

models including organic vapour concentration, which is calculated using the growth rate. However, as the order of magnitude estimates these values should be reliable.

\subsubsection{Sensitivity related to the made assumptions and to possible differences in CIMSs}

The assumptions made in estimating the concentration [org] and studying its effect on the particle formation rate $J_{2}$ are listed in Table 5. The sensitivity of some of the nucleation coefficients to the OH-dependency, density and mass of the condensing organic vapour is also presented, as well as the sensitivity to possible systematic difference between the sulphuric acid concentrations measured with the UHEL CIMS used in Hyytiälä and the DWD CIMS used at the other sites. The sensitivity analysis was carried out by replacing the assumed values with minimum and maximum values shown in Table 5 and recalculating the nucleation coefficients. The sensitivity is expressed as factors with which the nucleation coefficient values in Table 3 and the median values in Table 4 need to be multiplied if the related minimum or maximum value is used. In case of the sensitivity to difference in CIMSs, the smallest and largest values presented were obtained by multiplying sulphuric acid concentrations in either Hyytiälä or at the other sites with the factor 0.5 or 2 (see Sect. 2.2.2).

The largest uncertainties in Table 5 arise from the possible difference between the CIMSs, with the largest change of one order of magnitude in the coefficient $K_{S A 1}$. However, the possible systematic error that results from the use of dif- ferent CIMSs cannot explain the difference in the site specific median values of $K$ in Hyytiälä $\left(K=1.4 \times 10^{-12} \mathrm{~cm}^{3} \mathrm{~s}^{-1}\right.$, Table 4) and in Melpitz or SPC $\left(K<4 \times 10^{-14} \mathrm{~cm}^{3} \mathrm{~s}^{-1}\right)$. If we assume that the UHEL CIMS used in Hyytiälä shows $50 \%$ lower concentrations than the DWD CIMS and, thus, multiply $\left[\mathrm{H}_{2} \mathrm{SO}_{4}\right]$ measured in Hyytiälä with the factor 2, the median value of $K$ in Hyytiälä decreases to $3.6 \times 10^{-13} \mathrm{~cm}^{3} \mathrm{~s}^{-1}$. This value is still an order of magnitude higher than the medians of $K$ in SPC and Melpitz.

\subsection{Discussion}

\subsubsection{The connections between $J_{2}$ and first order gas concentrations}

In Hyytiälä, Melpitz and SPC the neutral nucleation rate $J_{2}$ was closely connected to sulphuric acid concentration ( $\left.\left[\mathrm{H}_{2} \mathrm{SO}_{2}\right]\right)$, the correlation coefficients $R$ for the logarithms of these quantities were $0.58,0.68$ and 0.58 , respectively. However, in Hohenpeissenberg $J_{2}$ was clearly better coupled with the calculated concentration of low-volatility organic vapours ([org]), $R=0.61$, than with the sulphuric acid concentration $(R=0.17)$. The equally high correlation coefficient between $J_{2}$ and [org] in Hohenpeissenberg, compared to that between $J_{2}$ and $\left[\mathrm{H}_{2} \mathrm{SO}_{4}\right]$ at the other sites was quite remarkable, because the organic vapour concentration calculated using $\left[\mathrm{H}_{2} \mathrm{SO}_{4}\right]$ and growth rate involves definitely larger uncertainties than those connected to measured sulphuric acid concentration. 
Table 5. Upper panel: the initial assumptions used in the study. Lower panel: sensitivity analysis for the nucleation coefficients when the assumed $\mathrm{OH}$-dependency, density and mass of the low-volatility organic vapour are varied, and when the CIMSs are assumed to have systematic difference in measured sulphuric acid concentration. Tabulated values for nucleation coefficients represent the factors with which the median values of $A$ and $K$ in Table 4 and optimized coefficient values in Table 3 need to be multiplied if the corresponding minimum or maximum value is used.

\begin{tabular}{ll}
\hline Assumption & Reasoning \\
\hline$J_{2} \propto[\mathrm{org}] \propto \mathrm{GR}_{2-4}-\mathrm{GR}_{\mathrm{H}_{2} \mathrm{SO}_{4}}$ & $\begin{array}{l}\text { The main assumption tested in this study. If the compounds affecting } \\
\text { the initial growth and nucleation were totally or mostly different, adding } \\
{[\mathrm{org}] \text { in a model should decrease the correlation with observations. }}\end{array}$ \\
{$[\mathrm{org}]^{\mathrm{sat}} \leq 1000 \mathrm{~cm}^{-3}$} & $\begin{array}{l}\text { If the saturation vapour concentration of condensing organic vapour is } \\
\text { over } \sim 1000 \mathrm{~cm}^{-3} \text {, the concentration [org] from Eq. (4) is affected. Low } \\
\text { saturation vapour concentration is required for nucleating vapours. }\end{array}$
\end{tabular}

\begin{tabular}{|c|c|c|c|c|c|c|c|c|c|c|c|}
\hline Assumption & Min. value & Max. value & \multicolumn{9}{|c|}{ Related multipliers for nucleation coefficients from Tables 3 and 4} \\
\hline $\mathrm{GR}_{\mathrm{det}}=\mathrm{GR}$ & $\frac{\mathrm{GR}}{2}<\mathrm{GR}_{\mathrm{det}}$ & $\mathrm{GR}_{\operatorname{det}}<2 \times \mathrm{GR}$ & \multicolumn{9}{|c|}{$\begin{array}{l}\text { Non-systematic uncertainty of } \mathrm{GR}_{\mathrm{det}} \text { causes uncertainty in results } \\
\text { but does not affect the coefficient medians. }\end{array}$} \\
\hline$[\mathrm{org}] \propto[\mathrm{OH}]^{1}$ & {$[\mathrm{org}] \propto[\mathrm{OH}]^{0}$} & {$[\mathrm{org}] \propto[\mathrm{OH}]^{2}$} & $\begin{array}{l}1.1 \\
1.0\end{array}$ & $\begin{array}{l}1.2 \\
1.0\end{array}$ & $\begin{array}{l}1.0 \\
1.0\end{array}$ & $\begin{array}{l}1.0 \\
1.0\end{array}$ & $\begin{array}{l}1.0 \\
4.0\end{array}$ & $\begin{array}{l}1.1 \\
0.8\end{array}$ & $\begin{array}{l}1.1 \\
3.2\end{array}$ & $\begin{array}{l}0.7 \\
0.7\end{array}$ & $\begin{array}{l}1.9 \\
0.4\end{array}$ \\
\hline$m($ org $)=168 \mathrm{amu}$ & $84 \mathrm{amu}$ & $336 \mathrm{amu}$ & $\begin{array}{l}1.0 \\
1.0\end{array}$ & $\begin{array}{l}1.0 \\
1.0\end{array}$ & $\begin{array}{l}1.0 \\
1.0\end{array}$ & $\begin{array}{l}0.6 \\
1.6\end{array}$ & $\begin{array}{l}1.0 \\
1.0\end{array}$ & $\begin{array}{l}0.6 \\
1.6\end{array}$ & $\begin{array}{l}1.0 \\
1.0\end{array}$ & $\begin{array}{l}0.6 \\
1.6\end{array}$ & $\begin{array}{l}0.4 \\
2.5\end{array}$ \\
\hline $\begin{array}{l}\text { No systematic difference in } \\
{\left[\mathrm{H}_{2} \mathrm{SO}_{4}\right] \text { by different CIMSs. }}\end{array}$ & $\begin{array}{l}\text { Systematic dif } \\
\text { of factor } 0.5 \text { or }\end{array}$ & $\begin{array}{l}\text { erence } \\
2\end{array}$ & $\begin{array}{l}0.7 \\
1.7\end{array}$ & $\begin{array}{l}0.6 \\
2.5\end{array}$ & $\begin{array}{l}0.5 \\
1.7\end{array}$ & $\begin{array}{l}0.8 \\
1.4\end{array}$ & $\begin{array}{l}0.1 \\
5.1\end{array}$ & $\begin{array}{l}0.8 \\
1.5\end{array}$ & $\begin{array}{l}0.2 \\
7.3\end{array}$ & $\begin{array}{l}0.5 \\
1.0\end{array}$ & $\begin{array}{l}0.9 \\
2.6\end{array}$ \\
\hline
\end{tabular}

When the sum of the gas concentrations $\left(\left[\mathrm{H}_{2} \mathrm{SO}_{4}\right]+[\right.$ org $\left.]\right)$ was investigated instead of [org] solely, the correlation in HPB, $R=0.61$, was equal to that of $J_{2}$ and [org]. This could be expected, since in HPB the calculated organic vapour concentration was almost an order of magnitude higher than the sulphuric acid concentration. At all the other measurement sites the connection between $J_{2}$ and the sum is clearly weaker than between $J_{2}$ and sulphuric acid alone.

The highest correlation coefficient and smallest variation for the entire dataset, $R=0.70$ and $V_{90 / 10}=10$, were achieved with the model involving the sum of the vapour concentrations with separate sulphuric acid and organic activation coefficients $A_{\mathrm{s} 1}=6.1 \times 10^{-7} \mathrm{~s}^{-1}$ and $A_{\mathrm{s} 2}=3.9 \times 10^{-8} \mathrm{~s}^{-1}$ (Eq. 18). For Hyytiälä, Melpitz and SPC individually these nucleation coefficients produced a practically equal correlation and variation as pure sulphuric acid activation. In HPB, the above-mentioned separate activation coefficients resulted in a weaker correlation and a bit larger variation than with organic vapour concentration alone or with one coefficient $A_{\mathrm{s}}$ multiplying the sum of concentrations. Nevertheless, in all the models for activation type nucleation mechanisms the site-specific datasets seemed to demand slopes steeper than one (Figs. 4 and 8 ) and, thus, these models did not describe the nucleation rate reliably.

\subsubsection{The connections between $J_{2}$ and second order vapour concentrations}

The models related to the homogenous nucleation of one of the vapours solely (Eqs. 11 and 13) led to large variations of the coefficient $K$ or $K_{\text {org }}$ when all the data are examined together $\left(V_{90 / 10}=174\right.$ and 202, respectively). However, by analysing the variations of the data from the individual sites, we observed that in Hyytiälä the variation of the coefficient $K$ was twice as large as the variation of coefficient $A$, and in Melpitz and SPC the difference was even smaller. In HPB the variation of $K_{\text {org }}$ was also approximately twice as large as that of $A_{\text {org. }}$. As discussed in Sect. 2.4.2, these differences of variations between the models using first and second order vapour concentrations can be expected to result from the propagating uncertainty when the vapour concentration is squared. Visual estimation of the slopes for the separate sites from the figures $J_{2}$ vs. [vapour] ${ }^{n}$ resulted in favour of $n=2$ (Figs. 5 and 6).

The site-specific median values for coefficient $K$ varied by almost two orders of magnitude, from $K<4 \times 10^{-14} \mathrm{~cm}^{3} \mathrm{~s}^{-1}$ in Melpitz and SPC to $K=1.4 \times 10^{-12} \mathrm{~cm}^{3} \mathrm{~s}^{-1}$ in Hyytiälä (Table 4). Kuang et al. (2008) have reported kinetic coefficient values related to varying continental air mass types 
in the range $1.6 \times 10^{-14}-1.6 \times 10^{-11} \mathrm{~cm}^{3} \mathrm{~s}^{-1}$, with which our results agreed well. Their best fit value for the kinetic coefficient during two nucleation events in March 2003 in Hyytiälä was $4.0 \times 10^{-13} \mathrm{~cm}^{3} \mathrm{~s}^{-1}$, with $90 \%$ confidence intervals from $1.3 \times 10^{-13}$ to $1.2 \times 10^{-12} \mathrm{~cm}^{3} \mathrm{~s}^{-1}$.

Combining the rather small site-specific $V_{90 / 10}$ values for coefficient $K$ with the remarkable difference in the sitespecific medians, we may suggest some interpretations for this: (i) if the homogenous sulphuric acid nucleation is the only nucleation mechanism (in the other stations than HPB), the coefficient $K$ must be dependent on some quantity, which differs significantly between Hyytiälä and Melpitz/SPC, or (ii) there is some other nucleation mechanism in addition to the homogenous $\mathrm{H}_{2} \mathrm{SO}_{4}$ nucleation taking place especially in Hyytiälä.

The model of homogenous heteromolecular nucleation mechanism proposing the connection $J=K_{\text {het }}\left[\mathrm{H}_{2} \mathrm{SO}_{4}\right]$ [org] resulted in a strong correlation for the whole dataset $(R=0.59)$, and a quite strong correlation in Hyytiälä, Hohenpeissenberg and SPC separately $(0.51,0.47$ and 0.47 , respectively). On the other hand, in Melpitz, where the sulphuric acid concentration was higher than the organic vapour concentration, the correlation was clearly weaker $(R=0.27)$ than for the mechanisms connecting $J$ with the sulphuric acid concentration solely.

When both heteromolecular and homomolecular $\mathrm{H}_{2} \mathrm{SO}_{4}$ nucleation were assumed to take place, i.e., $J=K_{\mathrm{SA}}$ $\left(\left[\mathrm{H}_{2} \mathrm{SO}_{4}\right]^{2}+\left[\mathrm{H}_{2} \mathrm{SO}_{4}\right][\mathrm{org}]\right)$, the strongest correlation ( $R=0.67$ ) for the models with a single nucleation coefficient was achieved. Additionally, the variations for the whole dataset, and for the individual sites other than HPB, were small compared to those of other modelled mechanisms connected to second order vapour concentrations. However, the estimated slope connecting the logarithms of modelled and observed particle formation rates from the whole dataset does not seem to be one. This can be seen in Fig. 7 as the data points of Melpitz and SPC datasets should be moved either up or left in order to achieve the overall slope one.

Introducing the separate nucleation coefficients $K_{\mathrm{SA} 1}$ and $K_{\mathrm{SA} 2}$ (Eq. 19) or adding a term of homogenous homomolecular organic vapour nucleation (Eq. 20) did not change significantly the correlation or variation achieved with a single nucleation coefficient $K_{\mathrm{SA}}$. However, the separate coefficients in Eq. (19) with values $K_{\mathrm{SA} 1}=1.1 \times 10^{-14} \mathrm{~cm}^{3} \mathrm{~s}^{-1}$ and $K_{\mathrm{SA} 2}=3.2 \times 10^{-14} \mathrm{~cm}^{3} \mathrm{~s}^{-1}$ and in Eq. (20) with $K_{\mathrm{s} 1}=1.4 \times 10^{-14}, K_{\mathrm{s} 2}=2.6 \times 10^{-14}$ and $K_{\mathrm{s} 3}=3.7 \times 10^{-16} \mathrm{~cm}^{3} \mathrm{~s}^{-1}$ brought the modelled formation rate in Melpitz closer to the observed rate (Fig. 9). On the other hand, even with these coefficients the modelled formation rate in SPC remains higher than the observed $J_{2}$ especially with the lower observed formation rates. Also in Melpitz the formation rate was overestimated by these models in data points with the lowest observed formation rates. Thus, the estimated slopes for SPC and Melpitz data seem to be larger than unity.

\subsubsection{On the correlation between $J_{2}$ and $\mathbf{G R}_{2-4}$}

Correlation between $J_{2}$ and the growth rate of the particles from 2 to $4 \mathrm{~nm}$ was significant $(R>0.4)$ when calculated for the whole dataset from four sites, and for the HPB measurement station alone (Table 2). Thus, one could suspect that the GR dependence of $J_{2}^{\text {tot }}$ (Eq. 7) is the reason for the correlations between $J_{2}$ and the modelled nucleation mechanisms involving [org] derived from GR (Eqs. 3 and 4). This suspicion is justified, since the GR-term in Eq. (7) covers over $50 \%$ of the total $J_{2}^{\text {tot }}$ in some data points. On the other hand, the correlation is inevitable, because the same vapours are expected to take part in both the formation and initial growth of the particles. The most convincing modelled mechanisms (Eqs. 16, 19 and 20) resulted in stronger correlations between the observed and modelled nucleation rates than the correlations between $J_{2}$ and GR in all measurement sites except HPB. This implies that the correlations are not only due to the GR dependence of $J_{2}$.

The other reason to be suspicious of the use of GR is that the diameter of $2 \mathrm{~nm}$ might be larger than the diameter of the critical stable cluster. Thus, the formation rate of $2 \mathrm{~nm}$ particles can be dependent on the growth rate also due to physical reasons. In order to examine this, we calculated the formation rate of $1.2 \mathrm{~nm}$ particles (diameter of the critical cluster as suggested by Sipilä et al., 2010) with the method presented by Kerminen and Kulmala (2002) and used this $J_{1.2}$ in the model comparisons instead of $J_{2}$ (results not shown). This diminished the overall variations $V_{90 / 10}$ related to all of the modelled kinetic mechanisms. The variations related to $K$, $K_{\text {org }}, K_{\text {het }}, K_{\mathrm{SA}}$ and $K_{\mathrm{S}}$ decreased to values $171,180,26,25$ and 56, respectively (compared to 174, 202, 33, 30 and 71 in Table 2). The variations achieved with separate kinetic nucleation coefficients for each term in Eqs. (19) and (20) also diminished, from 28 and 25 to 23 and 21, respectively. On the contrary, all the variations related to the activation-type models remained as in Table 2, or increased (variations related to $A$ and $A_{\text {org }}$, from 12 to 14 , and from 39 to 47 , respectively), and the variation related to $J=B \mathrm{GR}_{2-4}$ increased from 21 to 22 . The remarkable decrease of all the kinetic nucleation coefficients seems to indicate that the achieved correlations between $J_{2}$ and kinetic models involving [org] can not be explained by just the growth from the critical cluster to a particle with a diameter of $2 \mathrm{~nm}$, but instead, that the nucleation mechanism itself is connected to those organic vapours, which affect the initial growth of the particles.

\subsubsection{The different behaviour of the formation rate in HPB}

The closer connection of $J_{2}$ with [org] than with $\left[\mathrm{H}_{2} \mathrm{SO}_{4}\right]$ in Hohenpeissenberg, while on all the other sites the $\left[\mathrm{H}_{2} \mathrm{SO}_{4}\right]$ seemed to be the main determinant of $J_{2}$, cannot be explained by what has been stated above. Hohenpeissenberg differs from most of the measurement sites also in terms of 
nucleation event frequency, by having the frequency maximum during the cold season instead of spring or summer (Birmili et al., 2003; Paasonen et al., 2009). It is possible that in HPB some specific low-volatility organic vapour is present in contrast to the other measurement sites, which then should be almost as active in activating the clusters or more active in nucleating homogenously than sulphuric acid. On the other hand, the different behaviour might also be related to the HPB station being located on the mountain top over $300 \mathrm{~m}$ above the surroundings. For example, Boulon et al. (2010) showed that at a high-altitude Alpine site the nucleation event frequency did not correlate with sulphuric acid concentration, and Rodrigues et al. (2009) have reported different behaviour of the nucleation events depending on the season at the mountain site of Teneriffe. Unfortunately, in our data there were very few analysable nucleation events in HPB during the late spring and summer months, the time when the measurements were performed at the other sites, due to the involvement of the Hohenpeissenberg CIMS in the Melpitz and SPC campaigns. Thus, a detailed comparison of data from the same season as those of the other stations is currently not possible, but the two nucleation events recorded during spring/summer do not show a correlation between nucleation rate and sulphuric acid concentration, either. Furthermore, measurements at HPB are continuously running and corresponding data should become available soon.

\section{Conclusions}

We evaluated the concentration of the vapours other than sulphuric acid condensing on 2 to $4 \mathrm{~nm}$ particles by subtracting the calculated growth rate related to sulphuric acid condensation from the observed growth rate of these particles. We used the method presented by Nieminen et al. (2010) to calculate the growth rate related to sulphuric acid condensation, and further to estimate the concentration of the vapours inducing the rest of the growth by assuming that these other vapours are low-volatility organic vapours, as suggested by, e.g., Kulmala et al. (2004b) and Paasonen et al. (2009). This low-volatility organic vapour concentration was used in order to find out whether and how it affects the formation rate of $2 \mathrm{~nm}$ sized neutral particles $\left(J_{2}\right)$, determined from particle size distributions. The analysis was made for datasets collected during EUCAARI-campaigns between the years 2007 and 2009 at four European measurement sites (Hyytiälä/Finland, Hohenpeissenberg and Melpitz/Germany, and San Pietro Capofiume/Italy). The data showed a wide range of particle formation and growth rates (over three and two orders of magnitude, respectively).

We tested the models of several nucleation mechanisms, including activation- (Kulmala et al., 2006) and kinetic-type (McMurry and Friedlander, 1979) sulphuric acid nucleation mechanisms, and six additional mechanisms involving lowvolatility organic vapours. These mechanisms were analo- gous to activation and kinetic theories, but they utilized lowvolatility organic vapour concentrations alone or together with sulphuric acid concentrations instead of sulphuric acid concentrations alone. One of them, the heteromolecular homogeneous nucleation mechanism, has already been investigated in laboratory conditions by Metzger et al. (2010).

The models of the different nucleation mechanisms were compared on the basis of the following characteristics and methods: (i) the correlation coefficient $R$ between the logarithms of the observed and modelled neutral nucleation rate, (ii) the variation $V_{90 / 10}$, i.e., the ratio of 90 th and 10 th percentiles of the data point-specific ratio between the observed and modelled formation rates, and (iii) visual analysis of the figures presenting the observed against the predicted formation rate (both in logarithmic scale), and more specifically, how close to slope one the data points of both the whole dataset and site-specific datasets in these figures were. If the slope significantly differs from one, the physical reasoning behind the mechanism does not hold. For all the modelled mechanisms with more than one term (i.e. two or more mechanisms are assumed to produce particles simultaneously), the comparison was made both with a single nucleation coefficient connecting the observed and modelled nucleation rates and with separate nucleation coefficients for each term.

A remarkable result of our study was that at Hohenpeissenberg the nucleation rate behaved differently than at the other sites: whereas at the other sites the correlation between $J_{2}$ and sulphuric acid concentration was strong $(R>0.55)$ and that between $J_{2}$ and organic vapour concentration not $(R<0.30)$, in Hohenpeissenberg $J_{2}$ had a strong correlation with organic vapour concentration $(R=0.61)$ and a weak correlation with sulphuric acid concentration $(R=0.17)$. The different behaviour of the Hohenpeissenberg dataset may result from the location of the measurement site, which is on the top of the mountain ( $300 \mathrm{~m}$ above the surroundings), or from the long-term nature of the measurements, as the Hohenpeissenberg dataset includes nucleation events from all seasons, whereas the other data were recorded during spring and summer months only. However, also the two nucleation events observed in HPB during spring/summer were in contrast to coupling between nucleation rate and sulphuric acid concentration.

The smallest variations $V_{90 / 10}$ for the whole dataset were achieved with the models describing the cluster activation by sulphuric acid alone $J=A\left[\mathrm{H}_{2} \mathrm{SO}_{4}\right]\left(V_{90 / 10}=12\right)$, and by both sulphuric acid and organic vapours with separated nucleation coefficients $J=A_{\mathrm{s} 1}\left[\mathrm{H}_{2} \mathrm{SO}_{4}\right]+A_{\mathrm{s} 2}[\mathrm{org}]$, where $A_{\mathrm{s} 1}=6.1 \times 10^{-7} \mathrm{~s}^{-1}$ and $A_{\mathrm{s} 2}=3.9 \times 10^{-8} \mathrm{~s}^{-1} \quad\left(V_{90 / 10}=10\right)$. Furthermore, the highest correlation coefficient related to the studied models, $R=0.70$, was also achieved with the latter of these activation mechanisms. However, by analysing the figures related to these models (Figs. 4 and 8), we realized that even though with these mechanisms the data points of the whole dataset produced a slope very close to one, the site specific datasets were clearly better described with a steeper 
slope. Thus, the activation mechanisms do not describe the nucleation process reliably.

By the general inspection of the $V_{90 / 10}$-values achieved with the different models, we concluded that the kinetictype mechanisms connected to second order vapour concentrations resulted in larger variations. This behaviour is reasonable due to the propagation of error when the measured and approximated vapour concentrations are multiplied or squared. Hence, the site specific variations for the sulphuric acid kinetic nucleation theory $J=K\left[\mathrm{H}_{2} \mathrm{SO}_{4}\right]^{2}$ at the sites other than Hohenpeissenberg were relatively small $\left(V_{90 / 10}<20\right)$, but the high variation for the whole dataset $\left(V_{90 / 10}=174\right)$ revealed that there is some clear difference between the sites affecting the nucleation. This variation was also seen in the site-specific median values of the coefficient $K$, varying from $3.3 \times 10^{-14} \mathrm{~cm}^{3} \mathrm{~s}^{-1}$ in Melpitz to $1.4 \times 10^{-12} \mathrm{~cm}^{3} \mathrm{~s}^{-1}$ in Hyytiälä. Nevertheless, based on the visual observation, the modelled kinetic nucleation mechanisms, of organic vapours in Hohenpeissenberg and sulphuric acid at the other sites, described the site-specific data clearly better than the modelled activation mechanisms.

When taking into account all the three factors we used for estimating the representativity of the models ( $R, V_{90 / 10}$, and the slope in figures), the most promising modelled mechanisms seemed to be the homogenous, i.e., kinetic-type nucleation of sulphuric acid both homomolecularly and heteromolecularly with the lowvolatility organic vapours, with or without the homomolecular nucleation of the organic vapours. By using, in $J=K_{\mathrm{SA}_{1}}\left[\mathrm{H}_{2} \mathrm{SO}_{4}\right]^{2}+K_{\mathrm{SA}_{2}}\left[\mathrm{H}_{2} \mathrm{SO}_{4}\right][$ org], the values $K_{\mathrm{SA} 1}=1.1 \times 10^{-14} \mathrm{~cm}^{3} \mathrm{~s}^{-1}$ and $K_{\mathrm{SA} 2}=3.2 \times 10^{-14} \mathrm{~cm}^{3} \mathrm{~s}^{-1}$, a good correlation for the whole dataset was achieved $(R=0.64$, $\left.V_{90 / 10}=28\right)$. With these nucleation coefficient values, the lowest correlation coefficient for the separate sites was $R=0.46$ and largest variation $V_{90 / 10}=31$, which is reasonably low when resulting from a model related to second order vapour concentrations. With this model the slope for the whole dataset in the figure presenting the logarithm of observed nucleation rate vs. the logarithm of modelled nucleation rate, was quite close to one. However, like all the other kinetic models, this model also predicted somewhat higher $J_{2}$ in San Pietro Capofiume than actually observed. Inserting a term of homomolecular organic vapour nucleation, i.e., $J=K_{\mathrm{s} 1}\left[\mathrm{H}_{2} \mathrm{SO}_{4}\right]^{2}+K_{\mathrm{s} 2}\left[\mathrm{H}_{2} \mathrm{SO}_{4}\right][\mathrm{org}]+K_{\mathrm{s} 3}[\mathrm{org}]^{2}$, with the values $K_{\mathrm{s} 1}=1.4 \times 10^{-14}, K_{\mathrm{s} 2}=2.6 \times 10^{-14}$ and $K_{\mathrm{s} 3}=3.7 \times 10^{-16} \mathrm{~cm}^{3} \mathrm{~s}^{-1}$, did not remarkably change the results $\left(R=0.65, V_{90 / 10}=25\right)$. The fact that the best results were achieved by modelling these two mechanisms is promising, since particle formation via both homomolecular sulphuric acid nucleation, with atmospherically relevant concentrations of $\mathrm{H}_{2} \mathrm{SO}_{4}$ (Sipilä et al., 2010), and heteromolecular nucleation between sulphuric acid and organic vapours (Metzger et al., 2010) have been recently reported in laboratory conditions.
Due to a large number of uncertainties in the measurements, the determination of the growth rates, the parameterization of the time dependence of the growth rates and the associated determination of the organic vapour concentrations, the presented values of the nucleation coefficients connecting $J_{2}$ and the vapour concentrations, are not assumed to be exact. Nevertheless, they should provide at least good order of magnitude estimates.

Our results also suggest that condensable vapours other than sulphuric acid, presumably oxidized organic vapours, do play a role in atmospheric nucleation. The dataset included three subsets presenting clearly separable connections between sulphuric acid concentration and nucleation rate: two showing good agreement with kinetic sulphuric acid nucleation mechanism, but with over an order of magnitude difference in the median nucleation coefficient (Hyytiälä and SPC/Melpitz), and one (HPB) with weak correlation between sulphuric acid and nucleation. By assuming simultaneous kinetic nucleation mechanisms, one related to sulphuric acid alone and other(s) involving the growth equivalent vapours, all these subsets could be modelled with simple equations. However, none of the modelled nucleation mechanisms resulted in closure. Furthermore, the reason for the deviant behaviour of the Hohenpeissenberg dataset remained unexplained. Thus, more research on the role of condensable vapours in the nucleation process, including long-term measurements of sub $5 \mathrm{~nm}$ particle size distributions and sulphuric acid concentration, is needed.

Acknowledgements. We would like to gratefully thank the Academy of Finland Center of Excellence programme (project number 1118615), European Commission 6th Framework programme project EUCAARI (contract no 036833-2 EUCAARI), and the Maj and Tor Nessling Foundation (project number 2010212) for their financial support. We thank André Sonntag, Jonas Hesemann, Achim Grüner and Gerald Spindler (IfT Leipzig) in conjunction with the NAIS measurements in Melpitz.

Edited by: L. M. Russell

\section{References}

Aalto, P., Hämeri, K., Becker, E., Weber, R., Salm, J., Mäkelä, J., Hoell, C., O’Dowd, C. D., Karlson, H., Hansson, H.-C., Väkevä, M., Koponen, I. K., Buzorius, G., and Kulmala, M.: Physical characterization of aerosol particles during nucleation events, Tellus B, 53, 344-358, 2001.

Arneth, A., Monson, R. K., Schurgers, G., Niinemets, Ü., and Palmer, P. I.: Why are estimates of global terrestrial isoprene emissions so similar (and why is this not so for monoterpenes)?, Atmos. Chem. Phys., 8, 4605-4620, doi:10.5194/acp-8-46052008, 2008.

Asmi, E., Sipilä, M., Manninen, H. E., Vanhanen, J., Lehtipalo, K., Gagné, S., Neitola, K., Mirme, A., Mirme, S., Tamm, E., Uin, J., Komsaare, K., Attoui, M., and Kulmala, M.: Results of the first air ion spectrometer calibration and intercomparison workshop, 
Atmos. Chem. Phys., 9, 141-154, doi:10.5194/acp-9-141-2009, 2009.

Berresheim, H., Elste, T., Plass-Dülmer, C., Eisele, F. L., and Tanner, D. J.: Chemical ionization mass spectrometer for long-term measurements of atmospheric $\mathrm{OH}$ and $\mathrm{H}_{2} \mathrm{SO}_{4}$, Int. J. Mass Spectrom., 202, 91-109, 2000.

Birmili, W., Stratmann, F., and Wiedensohler A.: Design of a DMAbased size spectrometer for a large particle size range and stable operation, J. Aerosol Sci., 30(4), 549-553, 1999.

Birmili, W., Berresheim, H., Plass-Dülmer, C., Elste, T., Gilge, S., Wiedensohler, A., and Uhrner, U.: The Hohenpeissenberg aerosol formation experiment (HAFEX): a longterm study including size-resolved aerosol, $\mathrm{H}_{2} \mathrm{SO}_{4}, \mathrm{OH}$, and monoterpenes measurements, Atmos. Chem. Phys., 3, 361-376, doi:10.5194/acp-3-361-2003, 2003.

Boulon, J., Sellegri, K., Venzac, H., Picard, D., Weingartner, E., Wehrle, G., Collaud Coen, M., Bütikofer, R., Flückiger, E., Baltensperger, U., and Laj, P.: New particle formation and ultrafine charged aerosol climatology at a high altitude site in the Alps (Jungfraujoch, $3580 \mathrm{~m}$ a.s.l., Switzerland), Atmos. Chem. Phys., 10, 9333-9349, doi:10.5194/acp-10-9333-2010, 2010.

Boy, M., Kulmala, M., Ruuskanen, T. M., Pihlatie, M., Reissell, A., Aalto, P. P., Keronen, P., Dal Maso, M., Hellen, H., Hakola, H., Jansson, R., Hanke, M., and Arnold, F.: Sulphuric acid closure and contribution to nucleation mode particle growth, Atmos. Chem. Phys., 5, 863-878, doi:10.5194/acp-5-863-2005, 2005.

Clayes, M., Iinuma, Y., Szmigielski, R., Surratt, J. D., Blockhuys, F., Van Alsenoy, C., Böge, O., Sierau, B., Gomez-Gonzalez, Y., Vermeylen, R., Van der Veken, P., Shahgholi, M., Chan, A. W. H., Herrmann, H., Seinfeld, J. H., and Maenhaut, W.: Terpenylic acid and related compounds from the oxidation of $\alpha$-pinene: Implications for new particle formation and growth above forest, Environ. Sci. Technol., 43, 6976-6982, 2009.

Engler, C., Rose, D., Wehner, B., Wiedensohler, A., Brüggemann, E., Gnauk, T., Spindler, G., Tuch, T., and Birmili, W.: Size distributions of non-volatile particle residuals $\left(D_{p}<800 \mathrm{~nm}\right)$ at a rural site in Germany and relation to air mass origin, Atmos. Chem. Phys., 7, 5785-5802, doi:10.5194/acp-7-5785-2007, 2007.

Hallquist, M., Wenger, J. C., Baltensperger, U., Rudich, Y., Simpson, D., Claeys, M., Dommen, J., Donahue, N. M., George, C., Goldstein, A. H., Hamilton, J. F., Herrmann, H., Hoffmann, T., Iinuma, Y., Jang, M., Jenkin, M. E., Jimenez, J. L., Kiendler-Scharr, A., Maenhaut, W., McFiggans, G., Mentel, Th. F., Monod, A., Prévôt, A. S. H., Seinfeld, J. H., Surratt, J. D., Szmigielski, R., and Wildt, J.: The formation, properties and impact of secondary organic aerosol: current and emerging issues, Atmos. Chem. Phys., 9, 5155-5236, doi:10.5194/acp-95155-2009, 2009.

Hamed, A., Joutsensaari, J., Mikkonen, S., Sogacheva, L., Dal Maso, M., Kulmala, M., Cavalli, F., Fuzzi, S., Facchini, M. C., Decesari, S., Mircea, M., Lehtinen, K. E. J., and Laaksonen, A.: Nucleation and growth of new particles in Po Valley, Italy, Atmos. Chem. Phys., 7, 355-376, doi:10.5194/acp-7-355-2007, 2007.

Hamed, A., Birmili, W., Joutsensaari, J., Mikkonen, S., Asmi, A., Wehner, B., Spindler, G., Jaatinen, A., Wiedensohler, A., Korhonen, H., Lehtinen, K. E. J., and Laaksonen, A.: Changes in the production rate of secondary aerosol particles in Central Europe in view of decreasing $\mathrm{SO}_{2}$ emissions between 1996 and 2006,
Atmos. Chem. Phys., 10, 1071-1091, doi:10.5194/acp-10-10712010, 2010.

Hao, L. Q., Yli-Pirilä, P., Tiitta, P., Romakkaniemi, S., Vaattovaara, P., Kajos, M. K., Rinne, J., Heijari, J., Kortelainen, A., Miettinen, P., Kroll, J. H., Holopainen, J. K., Smith, J. N., Joutsensaari, J., Kulmala, M., Worsnop, D. R., and Laaksonen, A.: New particle formation from the oxidation of direct emissions of pine seedlings, Atmos. Chem. Phys., 9, 8121-8137, doi:10.5194/acp9-8121-2009, 2009

Hari, P. and Kulmala, M.: Station for measuring ecosystematmosphere relations (SMEAR II), Boreal Environ. Res., 10, 315-322, 2005.

Hirsikko, A., Laakso, L., Horrak, U., Aalto, P. P., Kerminen, V.M., and Kulmala, M.: Annual and size dependent variation of growth rates and ion concentrations in boreal forest, Boreal Environ. Res., 10, 357-369, 2005.

Hoppel, W. A.: Determination of the Aerosol Size Distribution from the Mobility Distribution of the Charged Fraction of Aerosols, J. Aerosol Sci., 9, 41-54, 1978.

Israël, H.: Atmospheric electricity, Israel Program for Scientific Translations, Jerusalem, Vol. 1, 1970.

Jaecker-Voirol, A.: Etude physico-chimique de la formation des aérosols: application aux "pluies acides" et la stratosphère, Thesis, Université Louis Pasteur, Dép. de Chimie, Strasbourg, France, 1988.

Jimenez, J. L., Canagaratna, M. R., Donahue, N. M., Prévôt, A. S. H., Zhang, Q., Kroll, J. H., DeCarlo, P. F., Allan, J. D., Coe, H., Ng, N. L., Aiken, A. C., Docherty, K. S., Ulbrich, I. M., Grieshop, A. P., Robinson, A. L., Duplissy, J., Smith, J. D., Wilson, K. R., Lanz, V. A., Hueglin, C., Sun, Y. L., Tian, J., Laaksonen, A., Raatikainen, T., Rautiainen, J., Vaattovaara, P., Ehn, M., Kulmala, M., Tomlinson, J. M., Collins, D. R., Cubison, M J. E., Dunlea, J., Huffman, J. A., Onasch, T. B., Alfarra, M. R., Williams, P. I., Bower, K., Kondo, Y., Schneider, J., Drewnick, F., Borrmann, S., Weimer, S., Demerjian, K., Salcedo, D., Cottrell, L., Griffin, R., Takami, A., Miyoshi, T., Hatakeyama, S., Shimono, A., Sun, J. Y., Zhang, Y. M., Dzepina, K., Kimmel, J. R., Sueper, D., Jayne, J. T., Herndon, S. C., Trimborn, A. M., Williams, L. R., Wood, E. C., Middlebrook, A. M., Kolb, C. E., Baltensperger, U., and Worsnop, D. R.: Evolution of organic aerosols in the atmosphere, Science, 326, 1525-1529, 2009.

Kannosto, J., Virtanen, A., Lemmetty, M., Mäkelä, J. M., Keskinen, J., Junninen, H., Hussein, T., Aalto, P., and Kulmala, M.: Mode resolved density of atmospheric aerosol particles, Atmos. Chem. Phys., 8, 5327-5337, doi:10.5194/acp-8-5327-2008, 2008.

Kerminen, V.-M. and Kulmala, M.: Analytical formulae connecting the "real" and "apparent" nucleation rate and the nuclei number concentration for atmospheric nucleation events, J. Aerosol Sci., 33, 609-622, 2002.

Kerminen, V.-M., Lihavainen, H., Komppula, M., Viisanen, Y., and Kulmala, M.: Direct observational evidence linking atmospheric aerosol formation and cloud droplet activation, Geophys. Res. Lett., 32, L14803, doi:10.1029/2005GL023130, 2005.

Kuang, C., McMurry, P. H., McCormick, A. V., and Eisele, F. L.: Dependence of nucleation rates on sulfuric acid vapor concentration in diverse atmospheric locations, J. Geophys. Res., 113, D10209, doi:10.1029/2007JD009253, 2008.

Kulmala, M., Dal Maso, M., Mäkelä, J. M., Pirjola, L., Väkevä, M., Aalto, P. P., Miikkulainen, P., Hämeri, K., and O’Dowd, C. D.: 
On the formation, growth and composition of nucleation mode particles, Tellus B, 53, 479-490, 2001.

Kulmala, M., Vehkamäki, H., Petäjä, T., Dal Maso, M., Lauri, A., Kerminen, V.-M., Birmili, W., and McMurry, P. H.: Formation and growth rates of ultrafine atmospheric particles: a review of observations, J. Aerosol Sci., 35, 146-176, 2004a.

Kulmala, M., Suni, T., Lehtinen, K. E. J., Dal Maso, M., Boy, M., Reissell, A., Rannik, Ü., Aalto, P., Keronen, P., Hakola, H., Bäck, J., Hoffmann, T., Vesala, T., and Hari, P.: A new feedback mechanism linking forests, aerosols, and climate, Atmos. Chem. Phys., 4, 557-562, doi:10.5194/acp-4-557-2004, 2004 b.

Kulmala, M., Lehtinen, K. E. J., and Laaksonen, A.: Cluster activation theory as an explanation of the linear dependence between formation rate of $3 \mathrm{~nm}$ particles and sulphuric acid concentration, Atmos. Chem. Phys., 6, 787-793, doi:10.5194/acp-6-787-2006, 2006.

Kulmala, M., Riipinen, I., Sipilä, M., Manninen, H. E., Petäjä, T., Junninen, H., Dal Maso, M., Mordas, G., Mirme, A., Vana, M., Hirsikko, A., Laakso, L., Harrison, R. M., Hanson, I., Leung, C., Lehtinen, K. E. J., and Kerminen, V.-M.: Toward direct measurement of atmospheric nucleation, Science, 318, 89-92, 2007.

Kulmala, M. and Kerminen, V.-M.: On the growth of atmospheric nanoparticles, Atmos. Res., 90, 132-150, 2008.

Kulmala, M., Asmi, A., Lappalainen, H. K., Carslaw, K. S., Pöschl, U., Baltensperger, U., Hov, Ø., Brenquier, J.-L., Pandis, S. N., Facchini, M. C., Hansson, H.-C., Wiedensohler, A., and O'Dowd, C. D.: Introduction: European Integrated Project on Aerosol Cloud Climate and Air Quality interactions (EUCAARI) - integrating aerosol research from nano to global scales, Atmos. Chem. Phys., 9, 2825-2841, doi:10.5194/acp-9-2825-2009, 2009.

Kurtén, T., Noppel, M., Vehkamäki, H., Salonen, M., and Kulmala, M.: Quantum chemical studies of hydrate formation of $\mathrm{H}_{2} \mathrm{SO}_{4}$ and $\mathrm{HSO}_{4}$, Boreal Environ. Res., 12, 431-453, 2007.

Laaksonen, A., Hamed, A., Joutsensaari, J., Hiltunen, L., Cavalli, F., Junkermann, W., Asmi, A., Fuzzi, S., and Facchini, M. C.: Cloud condensation nuclei production from nucleation events at a highly polluted region, Geophys. Res. Lett., 32, L06812, doi:10.1029/2004GL022092, 2005.

Laaksonen, A., Kulmala, M., O’Dowd, C. D., Joutsensaari, J., Vaattovaara, P., Mikkonen, S., Lehtinen, K. E. J., Sogacheva, L., Dal Maso, M., Aalto, P., Petäjä, T., Sogachev, A., Yoon, Y. J., Lihavainen, H., Nilsson, D., Facchini, M. C., Cavalli, F., Fuzzi, S., Hoffmann, T., Arnold, F., Hanke, M., Sellegri, K., Umann, B., Junkermann, W., Coe, H., Allan, J. D., Alfarra, M. R., Worsnop, D. R., Riekkola, M. -L., Hyötyläinen, T., and Viisanen, Y.: The role of VOC oxidation products in continental new particle formation, Atmos. Chem. Phys., 8, 2657-2665, doi:10.5194/acp-82657-2008, 2008.

Lehtinen, K. E. J. and Kulmala, M.: A model for particle formation and growth in the atmosphere with molecular resolution in size, Atmos. Chem. Phys., 3, 251-57, doi:10.5194/acp-3-251-2003, 2003.

Lihavainen, H., Kerminen, V.-M., Komppula, M., Hatakka, J., Aaltonen, V., Kulmala, M., and Viisanen, Y.: Production of "potential" cloud condensation nuclei associated with atmospheric new-particle formation in northern Finland, J. Geophys. Res., 108(D24), 4782, doi:10.1029/2003JD003887, 2003.

Makkonen, R., Asmi, A., Korhonen, H., Kokkola, H., Järvenoja, S.,
Räisänen, P., Lehtinen, K. E. J., Laaksonen, A., Kerminen, V.M., Järvinen, H., Lohmann, U., Bennartz, R., Feichter, J., and Kulmala, M.: Sensitivity of aerosol concentrations and cloud properties to nucleation and secondary organic distribution in ECHAM5-HAM global circulation model, Atmos. Chem. Phys., 9, 1747-1766, doi:10.5194/acp-9-1747-2009, 2009.

Manninen, H. E., Nieminen, T., Riipinen, I., Yli-Juuti, T., Gagné, S., Asmi, E., Aalto, P. P., Petäjä, T., Kerminen, V.-M., and Kulmala, M.: Charged and total particle formation and growth rates during EUCAARI 2007 campaign in Hyytiälä, Atmos. Chem. Phys., 9, 4077-4089, doi:10.5194/acp-9-4077-2009, 2009.

Manninen, H. E., Nieminen, T., Asmi, E., Gagné, S., Häkkinen, S., Lehtipalo, K., Aalto, P., Vana, M., Mirme, A., Mirme, S., Hõrrak, U., Plass-Dülmer, C., Stange, G., Kiss, G., Hoffer, A., Töro, N., Moerman, M., Henzing, B., de Leeuw, G., Brinkenberg, M., Kouvarakis, G. N., Bougiatioti, A., Mihalopoulos, N., O’Dowd, C., Ceburnis, D., Arneth, A., Svenningsson, B., Swietlicki, E., Tarozzi, L., Decesari, S., Facchini, M. C., Birmili, W., Sonntag, A., Wiedensohler, A., Boulon, J., Sellegri, K., Laj, P., Gysel, M., Bukowiecki, N., Weingartner, E., Wehrle, G., Laaksonen, A., Hamed, A., Joutsensaari, J., Petäjä, T., Kerminen, V.-M., and Kulmala, M.: EUCAARI ion spectrometer measurements at 12 European sites - analysis of new particle formation events, Atmos. Chem. Phys., 10, 7907-7927, doi:10.5194/acp-10-79072010, 2010.

McMurry, P. H. and Friedlander, S. K.: New particle formation in the presence of aerosol, Atmos. Environ., 13, 1635-1651, 1979.

Merikanto, J., Spracklen, D. V., Mann, G. W., Pickering, S. J., and Carslaw, K. S.: Impact of nucleation on global CCN, Atmos. Chem. Phys., 9, 8601-8616, doi:10.5194/acp-9-8601-2009, 2009.

Metzger, A., Verheggen, B., Dommen, J., Duplissy, J., Prevot, A. S., Weingartner, E., Riipinen, I., Kulmala, M., Spracklen, D. V., Carslaw, K. S., and Baltensperger, U.: Evidence for the role of organics in aerosol particle formation under atmospheric conditions, P. Natl. Acad. Sci., 107, 6646-6651, doi:10.1073/pnas.0911330107, 2010.

Mirme, S., Mirme, A., Minikin, A., Petzold, A., Hõrrak, U., Kerminen, V. -M., and Kulmala, M.: Atmospheric sub-3 nm particles at high altitudes, Atmos. Chem. Phys., 10, 437-451, doi:10.5194/acp-10-437-2010, 2010.

Nieminen, T., Manninen, H. E., Sihto, S.-L., Yli-Juuti, T., Mauldin III, R. L., Petäjä, T., Riipinen, I., Kerminen, V.-M., and Kulmala, M.: Connection of sulfuric acid to atmospheric nucleation in boreal forest, Environ. Sci. Technol., 43, 4715-4721, 2009.

Nieminen, T., Lehtinen, K. E. J., and Kulmala, M.: On condensational growth of clusters and nanoparticles in sub-10 nm size range, Atmos. Chem. Phys. Discuss., 10, 1693-1717, doi:10.5194/acpd-10-1693-2010, 2010.

O’Dowd, C. D., Aalto, P. P., Hämeri, K., and Kulmala, M.: Atmospheric particles from organic vapours, Nature, 416, 497-498, 2002.

Paasonen, P., Sihto, S.-L., Nieminen, T., Vuollekoski, H., Riipinen, I., Plass-Dülmer, C., Berresheim, H., Birmili, W., and Kulmala, M.: Connection between new particle formation and sulphuric acid at Hohenpeissenberg (Germany) including the influence of organic compounds, Boreal Environ. Res., 14, 616-629, 2009.

Pacifico, F., Harrison, S. P., Jones, C. D., and Sitch, S.: Isoprene 
emissions and climate, Atmos. Environ., 43, 6121-6135, 2009.

Petäjä, T., Mauldin, III, R. L., Kosciuch, E., McGrath, J., Nieminen, T., Paasonen, P., Boy, M., Adamov, A., Kotiaho, T., and Kulmala, M.: Sulfuric acid and $\mathrm{OH}$ concentrations in a boreal forest site, Atmos. Chem. Phys., 9, 7435-7448, doi:10.5194/acp9-7435-2009, 2009.

Pierce, J. R. and Adams, P. J.: Uncertainty in global CCN concentrations from uncertain aerosol nucleation and primary emission rates, Atmos. Chem. Phys., 9, 1339-1356, doi:10.5194/acp-91339-2009, 2009.

Riipinen, I., Sihto, S.-L., Kulmala, M., Arnold, F., Dal Maso, M., Birmili, W., Saarnio, K., Teinilä, K., Kerminen, V.-M., Laaksonen, A., and Lehtinen, K. E. J.: Connections between atmospheric sulphuric acid and new particle formation during QUEST III-IV campaigns in Heidelberg and Hyytidld, Atmos. Chem. Phys., 7, 1899-1914, doi:10.5194/acp-7-1899-2007, 2007.

Riipinen, I., Manninen, H. E., Yli-Juuti, T., Boy, M., Sipilä, M., Ehn, M., Junninen, H., Petäjä, T., and Kulmala, M.: Applying the Condensation Particle Counter Battery (CPCB) to study the water-affinity of freshly-formed $2-9 \mathrm{~nm}$ particles in boreal forest, Atmos. Chem. Phys., 9, 3317-3330, doi:10.5194/acp-93317-2009, 2009.

Rinne, J., Bäck, J., and Hakola, H.: Biogenic volatile organic compound emissions from the Eurasian taiga: current knowledge and future directions, Boreal Environ. Res., 14, 807-826, 2009.

Rodríguez, S., González, Y., Cuevas, E., Ramos, R., Romero, P. M., Abreu-Afonso, J., and Redondas, A.: Atmospheric nanoparticle observations in the low free troposphere during upward orographic flows at Izaña Mountain Observatory, Atmos. Chem. Phys., 9, 6319-6335, doi:10.5194/acp-9-6319-2009, 2009.

Rohrer, F. and Berresheim, H.: Strong correlation between levels of tropospheric hydroxyl radicals and solar ultraviolet radiation, Nature, 442, 184-187, 2006.

Sihto, S.-L., Kulmala, M., Kerminen, V.-M., Dal Maso, M., Petäjä, T., Riipinen, I., Korhonen, H., Arnold, F., Janson, R., Boy, M., Laaksonen, A., and Lehtinen, K. E. J.: Atmospheric sulphuric acid and aerosol formation: implications from atmospheric measurements for nucleation and early growth mechanisms, Atmos. Chem. Phys., 6, 4079-4091, doi:10.5194/acp-6-4079-2006, 2006.

Sipilä, M., Berndt, T., Petäjä, T., Brus, D., Vanhanen, J., Stratmann, F., Patokoski, J., Mauldin III, R. L., Hyvärinen, A.-P., Lihavainen, H., and Kulmala, M.: The role of sulphuric acid in atmospheric nucleation, Science, 327, 1243-1246, 2010.

Smith, J. N., Dunn, M. J., Van Reken, T. M., Iida, K., Stolzenburg, M. R., McMurry, P. H., and Huey, L. G.: Chemical composition of atmospheric nanoparticles formed from nucleation in Tecamac, Mexico: Evidence for an important role for organic species in nanoparticle growth, Geophys. Res. Lett., 35, L04808, doi:10.1029/2007GL032523, 2008.

Spracklen, D. V., Carslaw, K. S., Kulmala, M., Kerminen, V.-M., Sihto, S.-L., Riipinen, I., Merikanto, J., Mann, G. W., Chipperfield, M. P., Wiedensohler, A., Birmili, W., and Lihavainen, H.: Contribution of particle formation to global cloud condensation nuclei concentrations, Geophys. Res. Lett., 35, L06808, doi:10.1029/2007GL033038, 2008.
Taipale, R., Ruuskanen, T. M., Rinne, J., Kajos, M. K., Hakola, H., Pohja, T., and Kulmala, M.: Technical Note: Quantitative long-term measurements of VOC concentrations by PTR-MS measurement, calibration, and volume mixing ratio calculation methods, Atmos. Chem. Phys., 8, 6681-6698, doi:10.5194/acp8-6681-2008, 2008.

Tammet, H. and Kulmala, M.: Simulation tool for atmospheric aerosol nucleation bursts, J. Aerosol Sci., 36, 173-196, 2005.

Venzac, H., Sellegri, K., Laj, P., Villani, P., Bonasoni, P., Marinoni, A., Cristofanelli, P., Calzolari, F., Fuzzi, S., Decesari, S., Facchini, M. C., Vuillermoz, E., and Verza, G. P.: High Frequency New Particle Formation in the Himalayas, P. Natl. Acad. Sci., 105, 15666-15671, 2008.

Wang, M. and Penner, J. E.: Aerosol indirect forcing in a global model with particle nucleation, Atmos. Chem. Phys., 9, 239-260, doi:10.5194/acp-9-239-2009, 2009.

Wang, L., Khalizov, A. F., Zheng, J., Xu, W., Ma, Y., Lal, V., and Zhang, R: Atmospheric nanoparticles formed from heterogenous reactions of organics, Nature Geosci., 3, 238-242, doi:10.1038/NGEO778, 2010.

Weber, R. J., Marti, J. J., McMurry, P. H., Eisele, F. L., Tanner, D. J., and Jefferson, A.: Measurements of new particle formation and ultrafine particle growth rates at a clean continental site, J. Geophys. Res., 102, 4375-4385, 1997.

Whitehead, J. D., McFiggans, G. B., Gallagher, M. W., and Flynn, M. J.: Direct linkage between tidally driven coastal ozone deposition fluxes, particle emission fluxes, and subsequent CCN formation, Geophys. Res. Lett., 36, L04806, doi:10.1029/2008GL035969, 2009.

Wiedensohler, A., Cheng, Y. F., Nowak, A., Wehner, B., Achtert, P., Berghof, M., Birmili, W., Wu, Z. J., Hu, M., Zhu, T., Takegawa, N., Kita, K., Kondo, Y., Lou, S. R., Hofzumahaus, A., Holland, F., Wahner, A., Gunthe, S. S., Rose, D., Su, H., and Pöschl, U.: Rapid aerosol particle growth and increase of cloud condensation nucleus activity by secondary aerosol formation and condensation: A case study for regional air pollution in northeastern China, J. Geophys. Res., 114, D00G08, doi:10.1029/2008JD0101884, 2009.

York, D., Evensen, N. M., López Martinez, M., and De Basabe Delgado, J.: Unified equations for the slope, intercept, and standard errors of the best straight line, Am. J. Phys., 72(3), 367-375, 2004.

Yu, F. and Luo, G.: Simulation of particle size distribution with a global aerosol model: contribution of nucleation to aerosol and CCN number concentrations, Atmos. Chem. Phys., 9, 76917710, doi:10.5194/acp-9-7691-2009, 2009.

Zhang, R., Suh, I., Zhao, J., Zhang, D., Fortner, E. C., Tie, X., Molina, L. T., and Molina, M. J.: Atmospheric New particle formation enhanced by organic acids, Science, 304, 1487-1490, 2004.

Zhang, R., Wang, L., Khalizov, A. F., Zhao, J., Zheng, J., McGraw, R. L., and Molina, L. T.: Formation of nanoparticles of blue haze enhanced by anthropogenic pollution, P. Natl. Acad. Sci., 106, 17650-17654, 2009. 